\title{
PAMAM Dendrimer Nanomolecules Utilized as Drug Delivery Systems for Potential Treatment of Glioblastoma: A Systematic Review
}

This article was published in the following Dove Press journal: International Journal of Nanomedicine

\author{
Michael Fana (iD) ${ }^{1,2, *}$ \\ John Gallien (iD) $2,3, *$ \\ Bhairavi Srinageshwar (iD) $1-3$ \\ Gary L Dunbar iD ${ }^{2-5}$ \\ Julien Rossignol (D) ${ }^{1-3}$ \\ 'College of Medicine, Central Michigan \\ University, Mt. Pleasant, MI 48859, USA; \\ ${ }^{2}$ Field Neurosciences Institute Laboratory \\ for Restorative Neurology, Central \\ Michigan University, Mt. Pleasant, MI 48859, \\ USA; ${ }^{3}$ Program in Neuroscience, Central \\ Michigan University, Mt. Pleasant, MI 48859, \\ USA; ${ }^{4}$ Department of Psychology, Central \\ Michigan University, Mt. Pleasant, MI 48859, \\ USA; ${ }^{5}$ Field Neurosciences Institute, \\ St. Mary's of Michigan, Saginaw, MI 48604, \\ USA \\ *These authors contributed equally to this \\ work
}

\begin{abstract}
Glioblastoma (GB) is a grade IV astrocytoma that maintains a poor prognosis with respect to current treatment options. Despite major advancements in the fields of surgery and chemoradiotherapy over the last few decades, the life expectancy for someone with glioblastoma remains virtually unchanged and warrants a new approach for treatment. Poly(amidoamine) (PAMAM) dendrimers are a type of nanomolecule that ranges in size (between 1 and $100 \mathrm{~nm}$ ) and shape and can offer a new viable solution for the treatment of intracranial tumors, including glioblastoma. Their ability to deliver a variety of therapeutic cargo and penetrate the blood-brain barrier (BBB), while preserving low cytotoxicity, make them a favorable candidate for further investigation into the treatment of glioblastoma. Here, we present a systematic review of the current advancements in PAMAM dendrimer technology, including the wide spectrum of dendrimer generations formulated, surface modifications, core modifications, and conjugations developed thus far to enhance tumor specificity and tumor penetration for treatment of glioblastoma. Furthermore, we highlight the extensive variety of therapeutics capable of delivery by PAMAM dendrimers for the treatment of glioblastoma, including cytokines, peptides, drugs, siRNAs, miRNAs, and organic polyphenols. While there have been prolific results stemming from aggressive research into the field of dendrimer technology, there remains a nearly inexhaustible amount of questions that remain unanswered. Nevertheless, this technology is rapidly developing and is nearing the cusp of use for aggressive tumor treatment. To that end, we further highlight future prospects in focus as researchers continue developing more optimal vehicles for the delivery of therapeutic cargo.
\end{abstract}

Keywords: drug delivery, glioma, nanotechnology, tumor, astrocytoma, PAMAM dendrimers

\section{Glioblastoma and PAMAM Dendrimers}

Glioma is an umbrella term for tumors that arise in the brain and spinal cord classified based on the known or presumed cell of origin: astrocytomas, oligodendrogliomas, or ependymomas derived, respectively, from astrocytes, oligodendrocytes, or ependymal cells. ${ }^{1,2}$ Astrocytoma is further categorized into four grades based on the extent of dysplasia: pilocytic astrocytoma (grade I), low-grade astrocytoma (grade II), anaplastic astrocytoma (grade III), and glioblastoma (GB; grade IV). ${ }^{3}$ Gliomas may present with the following clinical symptoms and rarely metastasize: epileptic seizures, confusion, vision problems, personality changes, hearing and locomotor disabilities, cardiorespiratory changes, and pulmonary embolism and thrombosis. ${ }^{3}$
Correspondence: Julien Rossignol Program in Neuroscience and College of Medicine, Central Michigan University,

I 280 S. East Campus Drive, Moun

Pleasant, MI 48859 USA

Tel + I 989-774-3405

Fax + I 989-774-1215

Email rossilj@cmich.edu 
Gliomas are the most common tumor type in the central nervous system and constitute approximately $80 \%$ of all malignant brain tumors. ${ }^{4,5}$ In particular, GB is highly aggressive with a dismal prognosis of inevitable mortality. Its aggressive development is due to the extensive vascular endothelial tissue proliferation, parenchymal necrosis, high cell density, and nuclear atypia. Current theories postulate their origins as either evolving from preexisting secondary GB (low-grade astrocytoma) or as de novo mutations. $^{2}$ Median survival rate for patients undergoing surgical resection and chemoradiotherapy is approximately 14 months, with a less than $5 \%$ survival rate after 5 years. ${ }^{6,7}$ Within the last 2 decades, the use of chemotherapy for GB treatment has seen only minor improvements, most notably with replacement of carmustine, nimustine, and lomustine with temozolomide (TMZ) as first-line therapy. Despite this, TMZ with radiotherapy and surgical resection have only marginally improved survival rates beyond 5 years. ${ }^{8,9}$ Clearly, there is a need for more innovative treatment options and the use of nanomolecules may present as a viable solution.

Nanomolecules have been in use for decades in a variety of industrial sectors, including agriculture, construction, petroleum, and more recently, biomedical sciences. ${ }^{10-14}$ The term "nano" refers to their $1-100 \mathrm{~nm}$ size and they are capable of carrying biomolecules, nucleic acids, and drugs across the blood-brain barrier (BBB), making them ideal for use in nano-therapy. The fascination surrounding nanomolecules stems from their customizability based on the constructed size, distribution of surface molecules, and surface modifications and conjugations. As a result, they may be developed with notable variation in intrinsic properties, such as melting temperatures, diffusion capacity, solubility, and in some cases, quantum effects. ${ }^{15-18}$ Examples of other nanocarriers that have been utilized in drug delivery include liposomes, polymeric micelles, and carbon nanotubes, each with their own strengths and limitations. For example, liposomes are spherical vesicles that function as highly efficient drug carriers; however, they must be PEGylated in order to prevent aberrant immune responses. Polyethylene glycol (PEG) is a non-hydrophilic polymer that is non-toxic and non-immunogenic. Nevertheless, this essential coating of liposomes with PEG hinders endocytosis, the main route of uptake for liposomes to enter cells, thereby restricting drug delivery. ${ }^{19}$

Polymeric micelles are self-assembled nanostructures consisting of a core and a shell that are formed in aqueous solutions. ${ }^{20}$ While polymeric micelles have been shown to effectively cross the BBB, the amounts in which they do this are subtherapeutic via systemic administration. ${ }^{21}$ Therefore, it is important to enhance tumor-targeting specificity as well as developing a controlled release if they are to be used in the treatment of glioblastoma.

Carbon nanotubes are cylindrical molecules made of carbon atoms. Their high surface area allows them to absorb or conjugate with drugs, genes, and proteins. ${ }^{22}$ Perhaps the reason carbon nanotubes have not been a major player in the delivery of drugs in glioblastoma is due to their non-spherical shape - they have been reported to remain trapped within lymph nodes and take longer to clear than spherical nanocarriers such as liposomes and dendrimers.

Given the limitations in such aforementioned nanomolecules, this review will focus on PAMAM dendrimers and their use in delivering pharmacological agents, biomolecules, and peptides. ${ }^{23}$

First conceptualized by Buhleier and colleagues in 1978, dendrimers were synthesized in the late 1970s and patented in the early 1980s by Donald Tomalia at Dow Chemical Company. ${ }^{24}$ It was not until 1985 when Newkome and colleagues (2010) described the first example of divergently constructed cascade tree-like macromolecules, using sp3-carbon atoms as branching centers for the monomeric dendrons. ${ }^{25}$

Their potential has since resulted in a surge of research into their capabilities in the $1990 \mathrm{~s}$ and $2000 \mathrm{~s} .{ }^{26}$ Presently, the highest generation we can achieve is a little over 10 , but we can expect dendrimers in the two to three digit range in the near future. ${ }^{27}$ PAMAM dendrimers were then synthesized in 1985 and are now investigated for use in nano-therapy of various neurodegenerative disease processes, including GB, due to their ability to efficiently bioconjugate and encapsulate treatments for delivery across the BBB. ${ }^{28}$

The structure of a PAMAM dendrimer typically consists of three main parts: a core, a shell, and branches (generation). Its synthesis follows one of the two approaches: divergent or convergent. Divergent synthesis starts with the core followed by the addition of its arms outwards in a stepwise fashion. ${ }^{29,30}$ Conversely, convergent synthesis begins with what will become the surface and working its way inward to couple end groups to each arm. ${ }^{29,31}$ Scientists may choose the convergent or divergent approach based on what method best facilitates their overall aim or purpose - for instance, enhancing transfection efficacy of dendrimers into cells or utilizing core splitting to release packaged contents. With this 
model, various generations have since been produced, increasing in density, size, and surface terminals with each successive generation. For example, a generation 0 (G0) dendrimer is $1-\mathrm{nm}$ in diameter and has 4 functional terminal units on its surface. A G1 dendrimer will be 2-nm in diameter with 8 terminal units while a G2 dendrimer has 16 terminal units, and so forth (Figure 1). The shape of the dendrimer is influenced by its size and surface terminals. Interestingly, Naylor and colleagues (1989) found that generations 1-3 have relatively asymmetric shapes while generations 5-7 have a highly spherical formation with G4 representing a transitional shape. ${ }^{32}$

The core of a PAMAM dendrimer is localized within the center and is the focal point from which the dendrimer branches. It is of interest as different cores may be used to better compliment the delivery of specific cargo. For instance, G4 PAMAM dendrimers with a cystamine core (Cys) contain a disulfide bond (-S-S-). Upon entry into GB cells, dendrimers transition into their abridged form due to the interaction with intracellular glutathione $(\mathrm{GSH})$ which is found in increasing concentrations in cancer cells. ${ }^{33}$ The resulting thiol (-SH) terminal group after separation into two separate dendrons has further been shown to have additional anti-inflammatory properties. This is particularly important as inflammation surrounding the cancerous growth is an additional unintended contributing factor to the damage surrounding normal tissue parenchyma. Moreover, this split also releases the cargo held between

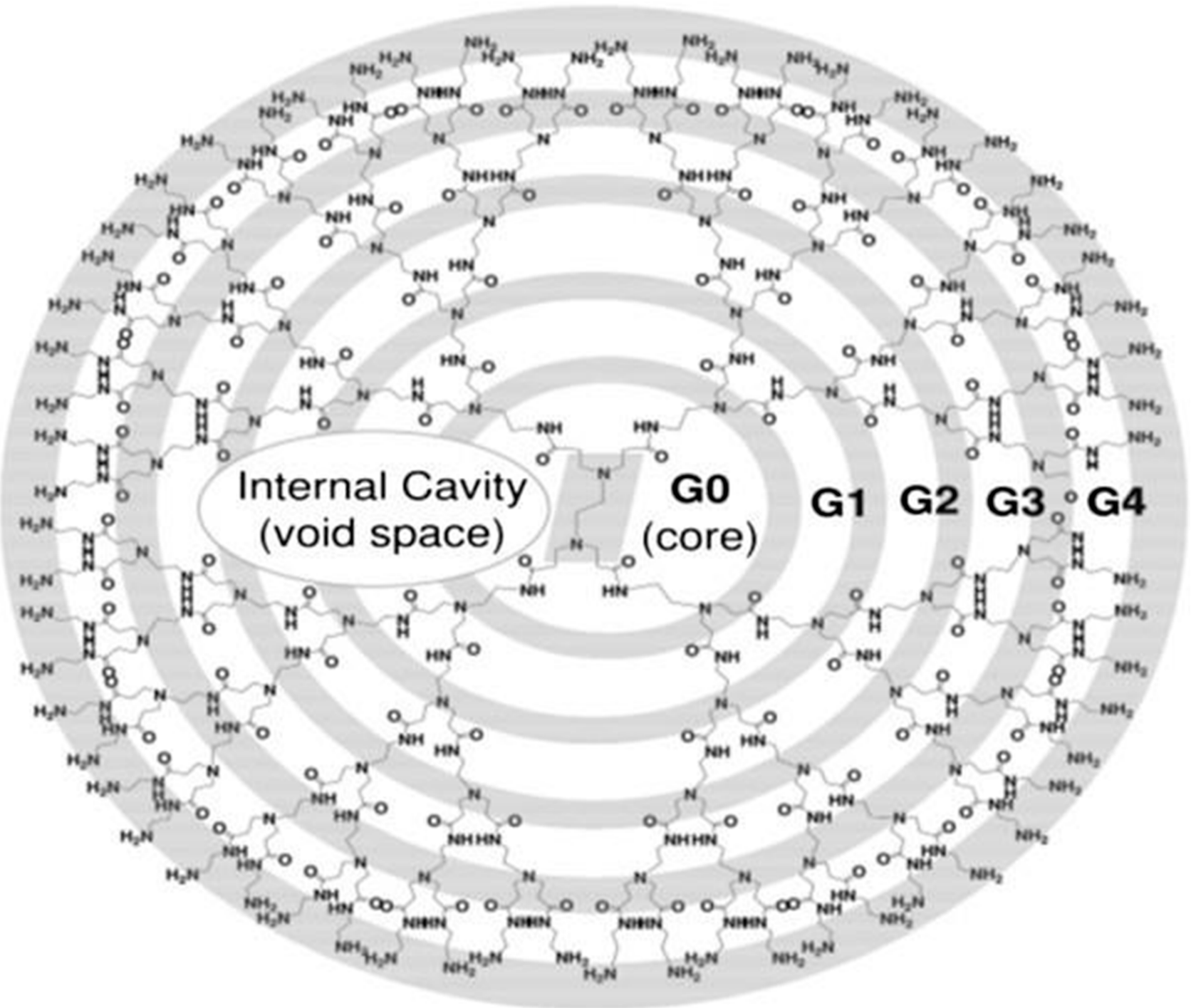

Figure I Schematic representation of a PAMAM dendrimer with an amine surface. Each successive amide layer branching outward from the core is represented by a new generation (ie, GI, G2, G3, etc.). The internal space of the dendrimer is void and permits encapsulation of cargo.

Notes: Reproduced from Abbasi E, Aval SF, Akbarzadeh A, et al. Dendrimers: synthesis, applications, and properties. Nanoscale Research Letters, 20I4;9(I):247. ${ }^{29}$ 
them. ${ }^{34}$ The dendrimer core also influences the space (ie, "void") between dendrons. For example, compared to a more standard ammonia core, a triethanolamine (TEA) core has several flexible ethylene glycol units, which expand the distance between dendrons, creating a larger void and enhancing the delivery of genes. ${ }^{35,36}$ On the other hand, PAMAM dendrimers with lipids at the core, such as those containing two octadecenyl chains, are useful in sofar as they help condense DNA into smaller dendriplexes (complex between dendrimers and DNA) with higher stability. ${ }^{37}$ Moving beyond the core, the construct of the shell affords another layer of creatively specific and unique PAMAM construct. The shell is the immediate layer of the dendrimer just beyond the core but has a different structure than that of the core material. ${ }^{38}$ For instance, the dendrimer shell can be constructed with a hydrophilic layer and used to encapsulate small RNA and drugs. ${ }^{39}$ Therefore, encapsulation of drugs with poor water solubility, and thus bioavailability, in PAMAM dendrimers is an efficient way to solubilize an otherwise nonsoluble or less soluble molecule or drug in aqueous solution. ${ }^{40}$ Presently, the size of the cavity limits the size of the cargo and discovering ways to create dendrimers with larger cavities that continue to have a stable structure is of great interest.

Dendrimers, like other nanomolecules, have an extremely high surface area-to-volume ratio. ${ }^{38}$ Changing the surface groups of a dendrimer changes their physical and chemical properties as well, such that the surface properties of some (eg, amine-surface PAMAM dendrimers) allow them to be transported across epithelial barriers to a greater extent than more conventional linear water-soluble polymers. ${ }^{41,42}$ The mechanism of dendrimer transport across epithelial cells is postulated to be an adsorptive-mediated endocytosis. ${ }^{43}$

Despite their efficacy and widespread application, PAMAM dendrimer cell toxicity is a concern. In fact, some of the first cationic dendrimers synthesized were found to be extremely toxic to cells in vivo. This is largely attributed to the interactions between the negatively charged biological membranes and the high positive surface charge density of cationic dendrimers. ${ }^{44}$ The toxicity of cationic PAMAM dendrimers, such as those with $100 \%$ amine surfaces, is well recorded and studies show an increasing toxicity with each succeeding generation. ${ }^{45,46}$ On the other hand, anionic PAMAM dendrimers that carry a neutral net charge due to terminal end units such as carboxylic acid (-COOH) or hydroxyls $(-\mathrm{OH})$ demonstrate low cell toxicity in vitro and in vivo. ${ }^{47}$ Therefore, modification of the PAMAM dendrimer surface can alter the cytotoxicity of the nanomolecules and increase their biocompatibility. ${ }^{48}$ Clearly, the ability to modify the core, branches, and surface of PAMAM dendrimers makes them versatile in their clinical applicability and viable as a potential treatment option for glioblastoma. ${ }^{49}$

While PAMAM dendrimers are often modified or adapted for specific functions, confirming their shape and specific ionic properties is essential in characterizing them for appropriate use. Commonly used assays for this are high-performance liquid chromatography (HPLC), mass spectrometry, capillary electrophoresis (CE), polyacrylamide gel electrophoresis (PAGE), and small-angle neutron scattering (SANS). ${ }^{50-53}$

HPLC is a technique that helps identify and quantify the separate components of a mixture or solution. ${ }^{50}$ The mixture is dissolved in a liquid solvent and pumped through a column containing a solid adsorbent material. Each separate component of the sample mixture will react differently with the adsorbent material, causing changes between their flow rates and ultimately, separation of components as they come out the opposite end of the column. $^{50}$

Mass spectrometry is a technique that measures the mass:charge ratio of ions. It is used mainly to determine the isotopic signature and masses of particles and molecules but can also be used to help identify the molecular structure of compounds. It can be used on both pure samples and mixtures. ${ }^{51}$

Capillary gel electrophoresis (CE) is an electro-kinetic method for separating analytes by ionic mobility. It is typically used to characterize low generation dendrimers, yet becomes problematic when characterizing later generations, due to their similarities in charge density and interactions with the wall of the capillary. Additionally, CE requires a trained operator and expensive instrumentation. ${ }^{52}$

Polyacrylamide gel electrophoresis (PAGE) is a much cheaper alternative for separating macromolecules and nanoparticles based on their size and charge. It has several advantages over CE. The test does not require a large sample size and is a non-destructive way of measuring dendrimers without causing fragmentation. Its ability in characterization can be used to detect and separate the various cores and surface groups, exhibited by improved separation and staining characteristics. ${ }^{52}$

Small-angle neutron scattering (SANS) is a technique which directs beams of neutrons at a sample which are then scattered by nuclear interaction. It measures these 
small scattering angles in order to elucidate the structure of substances on a mesoscopic scale $1-100 \mathrm{~nm} .^{53}$

While there is a substantial list of chemical assays which can be used to characterize and define PAMAM dendrimers, these are some of the more common and useful techniques currently being implemented in the field of nanotechnology. As the use of PAMAM dendrimers in the field of experimental nanomedicine grows and expands, so will the technological advancements used to characterize them.

Here we present an overview and review of the most current experiments utilizing PAMAM dendrimers as a potential treatment for GB. The salient details of these investigations are highlighted in Table 1 . Much of the studies with dendrimer technology is centered on the various therapeutics available and possible for delivery to GB cells in vitro and in vivo. These vary greatly from siRNAs to miRNAs, medications, cytokines, and other biomolecules. These investigations also examined the utility of various dendrimer surface modifications and conjugations to enhance delivery of unique cargo to GB cells, which warrants significant discussion and are highlighted in a comprehensive list in Tables 2 and 3.

\section{Earlier Investigations into Dendrimer Application for Glioblastoma}

Here we briefly describe the investigations undertaken in the earlier years of PAMAM dendrimer technology used for treatment of GB. The progressions since then have largely been focussed on developing a less cytotoxic, more permeating, and cell-specific targeted dendrimer construct. For instance, Perez and colleagues (2011) experimented with a larger G7 dendrimer complex which carried siRNA to T98G (GB) and J774 (macrophage) cells. ${ }^{34}$ Dendrimers of this size are seldom used as newer investigations have found that smaller dendrimers, such as G4, are more effective in crossing the BBB while as effective in delivering the cargo. Nonetheless, Perez and colleagues (2011) found that in T98G cells, the following treatments and respective resulting measures of reduction in glioblastoma cell proliferation were observed: MbetaCD - 75\%, genistein - 50\%, and chloroquine - 10-20\%. ${ }^{34}$ Yan and colleagues (2011) developed tumor cell target-specific dendrimers for drug delivery by developing a G5 PAMAM dendrimer complexed with tumor vasculature targeted cyclic peptides and BBB-permeable angiopep-2
Table I Dendrimer Shell Modification(s) and Conjugation(s) for the Respective Dendrimer Generation Investigated, Ordered from GI-G7

\begin{tabular}{|c|c|c|}
\hline Investigation & $\begin{array}{l}\text { Dendrimer } \\
\text { Construct(s) }\end{array}$ & $\begin{array}{l}\text { Dendrimer Shell } \\
\text { Conjugation/ } \\
\text { Modification(s) }\end{array}$ \\
\hline Choi et al $(2017)^{66}$ & GI & PEG-PLGA \\
\hline $\begin{array}{l}\text { Pedro-Hernandez et al } \\
(2017)^{72}\end{array}$ & $\mathrm{G} 1$ and $\mathrm{G} 2$ & $\begin{array}{l}\text { Ethyphenyl and dodecyl } \\
\text { alkyl }\end{array}$ \\
\hline $\begin{array}{l}\text { Stenström et al } \\
(2018)^{65}\end{array}$ & $\begin{array}{l}\text { GI-G4 } \\
\text { [2,2-bis(methylol) } \\
\text { propionic acid core] }\end{array}$ & $\begin{array}{l}\text { Ammonium } \\
\text { trifluoroacetate end } \\
\text { groups }\end{array}$ \\
\hline $\begin{array}{l}\text { Janiszewska et al } \\
(2016)^{73}\end{array}$ & G2 & Poly-L-lysine \\
\hline $\begin{array}{l}\text { Uram et al }(2018, \\
2019)^{78,79}\end{array}$ & G3 & Biotin \\
\hline Uram et al $(2017)^{63}$ & G3 & Biotin \\
\hline McNerny et al $(2009)^{57}$ & G3 & $c($ RGDyK) and biotin \\
\hline $\begin{array}{l}\text { Kaneshiro et al } \\
(2009)^{58}\end{array}$ & G3 & Poly-lysine \\
\hline Singh et al $(2019)^{59}$ & G3.5-G4 & $\begin{array}{l}\text { Ammine } \\
\text { Carboxyl }\end{array}$ \\
\hline Bae et al $(2019)^{60}$ & G4 & $\begin{array}{l}\text { Phenylalanine, histidine, } \\
\text { and arginine }\end{array}$ \\
\hline Munro et al $(2019)^{61}$ & G4 & Hydroxyl:amine (90:10) \\
\hline Wu et al $(2018)^{77}$ & G4 & PEG \\
\hline Liu et al $(2018)^{87}$ & G4 & $\begin{array}{l}\text { TAT } \\
\text { PEG }\end{array}$ \\
\hline Bae et al $(2017)^{71}$ & G4 & $\begin{array}{l}\text { Histidine and Arginine } \\
\text { Histidine and Lysine }\end{array}$ \\
\hline Bae et al $(2016)^{70}$ & G4 & $\begin{array}{l}\text { Histidine and Arginine } \\
\text { Histidine and Lysine }\end{array}$ \\
\hline Zhang et al $(2015)^{74}$ & G4 & $\begin{array}{l}\text { PEG } \\
\text { Hydroxyl }\end{array}$ \\
\hline Yang et al $(2014)^{88}$ & G4 & Gd-NGO \\
\hline Bai et al $(2013)^{89}$ & G4 & Arginine \\
\hline Qiu et al $(2018)^{62}$ & G5 & $\begin{array}{l}\beta-C D \text { moiety } \\
\mathrm{Au}\end{array}$ \\
\hline Lesniak et al $(2016)^{90}$ & G5 & N/A \\
\hline Jiang et al $(2016)^{75}$ & G5 & PEG \\
\hline Zhao et al $(2015)^{76}$ & G5 & PEG \\
\hline Yan et al $(2011)^{54}$ & G5 & PEG \\
\hline Ren et al $(2010)^{55}$ & G5 & N/A \\
\hline
\end{tabular}

(Continued) 
Table I (Continued).

\begin{tabular}{|l|l|l|}
\hline Investigation & $\begin{array}{l}\text { Dendrimer } \\
\text { Construct(s) }\end{array}$ & $\begin{array}{l}\text { Dendrimer Shell } \\
\text { Conjugation/ } \\
\text { Modification(s) }\end{array}$ \\
\hline Ofek et al $(2010)^{56}$ & G5 & Polyglycerol \\
\hline Perez et al $(2011)^{34}$ & G7 & N/A \\
\hline
\end{tabular}

peptides. ${ }^{54}$ The nanoprobe targets the integrin on tumor vasculatures and the LRP receptors on the vascular endothelial cells and the tumor cells, allowing the complex to specifically target U87MG GB xenograft cells. ${ }^{54}$

Finally, several earlier research investigations sought to identify various therapeutic agents that could be successfully delivered to tumor cell lines with notable effects, some of such agents having been previously described in the newer investigations. For instance, Ren and colleagues (2010) used human glioblastoma cells U251 (PTEN-mutant) and LN229 (PTEN wild-type) to treat with taxol and miR-21 inhibitors packaged in G5 PAMAM dendrimers either as a combination or individually. ${ }^{55}$ MiR-21 inhibitors downregulate miR-21 to allow for the anti-tumor effects of taxol. They found that U251 and LN229 cells treated with both miR-21 and taxol displayed significantly more apoptosis compared to taxol alone. ${ }^{55}$ Ofek et al (2010) developed a polymerized polyglycerol-based dendrimer (PEI-PAMAM) shell to deliver siRNA to silence luciferase (luc) in tumors in vivo. ${ }^{56}$ They found the nanocarriers exhibited low cytotoxicity and high efficacy in delivering active siRNA into GB and murine mammary adenocarcinoma cell lines. ${ }^{56}$ McNerny and colleagues (2009) synthesized G3 PAMAM dendrimers with c(RGDyK) peptide on the surface to conjugate biotin, methotrexate, or additional functionalized dendron at the focal point which targeted human glioblastoma cells (U87MG) in vitro. ${ }^{57}$ Kaneshiro and colleagues (2009) formulated a PLL dendrimer with a silsesquioxane cubic core (nanoglobules). ${ }^{58} \mathrm{G} 3$ nano-globular dendrimers were used to conjugate the peptide $\mathrm{c}$ (RGDfK) with a PEG spacer for delivery of doxorubicin and siRNA to U87 cells. The result was efficacious silencing in U87-Luc cells. ${ }^{58}$

\section{Recent Progress in PAMAM Dendrimer Technology Surface and Core Modifications}

One of the future directions of dendrimer synthesis consists of creating hybrid dendrimers composed of several different individual dendrimers into a nexus or nano- assembly. Previously, it has been shown that the release profile of drugs can be controlled by tuning the dendrimerto-drug ratio in assembly. Singh and colleagues (2019) mixed G4 PAMAM-( $\left.\mathrm{NH}_{2}\right)$ with G3.5 PAMAM- $(\mathrm{COOH})$ dendrimers along with the chemotherapeutic drug, Docetaxel (DTX), to form such a complex. ${ }^{59}$ DTX has well-documented toxic tissue effects and challenges with solubility and controlled drug release. Several nano-carrier systems have been able to improve its solubility and toxicity but failed to maintain controlled release due to premature leakage of the drug from its carriers. Singh and colleagues (2019) developed this next generation dendrimer hybrid for oral administration to improve drug solubility, oral bioavailability, and drug release profile. The solubility profile of docetaxel amine-dendrimer complex (A-DTX), docetaxel-sodium carboxylate dendrimer complexes (C-DTX), and docetaxel and amine-carboxylate hybrid dendrimer complexes AC-DTX (premix and in situ) were examined. Ultimately, AC-DTX showed the greatest solubility of the four complexes. Meanwhile, the storage stability of all complexes was unchanged over 180 days. In vitro cell viability experiments further demonstrated that dendrimer-DTX conjugates were toxic to U87MG (human primary glioblastoma) and GL261 (mouse glioma) cells at higher concentrations and nontoxic at nearly all concentrations in CHO and HEK-293 cells. Their results demonstrate that hybrid dendrimerbased nano-assemblies can be used to increase the physicochemical stability and bioavailability of commercially based drugs on a level that is comparable to intravenous administration, while minimizing cytotoxicity in noncancerous cells. ${ }^{59}$

While improving stability and bioavailability of dendrimer constructs is crucial, another major obstacle to overcome in the treatment of cancer is achieving high specificity to cancer cells while minimizing non-cancer cell cytotoxicity. This was the primary investigational premise of Bae and colleagues (2019) who designed a PAMAM dendrimer with phenylalanine, histidine, and arginine surface modifications (PAMAM-FHR). ${ }^{60}$ This construct delivered a tumor cell-specific gene, apoptin, to human primary glioma cell lines (GBL-14) and human dermal fibroblasts in vitro. Apoptin was complexed with PAMAM derivatives and cell lines treated with either PAMAM or PAMAM-FHR dendrimers at increasing doses over 24 and 48 hrs showed negligible toxicity in all cell lines. Transfection efficacy was measured in vitro to compare PAMAM and PAMAM-FHR dendrimers. The 
Table 2 Summary of All Investigations for Treatment of Glioblastoma with PAMAM Dendrimer Technology - Transfection of GB Cells and/Or Penetration of GB Tumor with Dendrimer

\begin{tabular}{|c|c|c|c|c|c|}
\hline Investigators & Cytotoxic Cargo & $\begin{array}{l}\text { Cell } \\
\text { Lines }\end{array}$ & Results & $\begin{array}{l}\text { Cell Viability } \\
\text { Measurement }\end{array}$ & Distribution Analyses \\
\hline Bae et al $(2019)^{60}$ & Apoptin & GBL-14 & $\begin{array}{l}\text { PAMAM-FHR showed improved apoptin gene } \\
\text { transfection efficacy vs PAMAM alone. } \\
\text { PAMAM-FHR/PJDK-apoptin complex demonstrated } \\
\text { apoptosis induction in the GBL-14 cell line with } \\
\text { minimal cytotoxicity in control dermal fibroblasts. }\end{array}$ & $\begin{array}{l}\text { [In vitro] EZ-Cytox } \\
\text { assay }\end{array}$ & N/A \\
\hline Qiu et al $(2018)^{62}$ & $\begin{array}{l}\text { B-cell lymphoma/ } \\
\text { leukemia-2 (Bcl-2) } \\
\text { siRNA } \\
\text { VEGF siRNA }\end{array}$ & U87MG & $\begin{array}{l}\text { Bcl-2 and VEGF-siRNA delivery with Au DENPs- } \beta \text { - } \\
C D \text { modified G5 dendrimers had high uptake of } \\
\text { vector polyplex and gene product silencing } \\
\text { capabilities and low cell cytotoxicity. }\end{array}$ & [In vitro] MTT assay & [In vitro] flow cytometry \\
\hline Liu et al $(2018)^{87}$ & KLAK & U87MG & $\begin{array}{l}\text { KLAK-TAT-PEG conjugated G4 dendrimers (PKT- } \\
\text { S-PEG) demonstrated enhanced U87MG } \\
\text { cytotoxicity via mitochondrial apoptosis as well as } \\
\text { increased depth of tumor penetration in U87MG } \\
\text { spheroids. }\end{array}$ & [In vitro] JC-I assay & N/A \\
\hline $\begin{array}{l}\text { Stenström et al } \\
(2018)^{65}\end{array}$ & P42-MAPK siRNA & $\begin{array}{l}\text { U87MG } \\
\text { C6 }\end{array}$ & $\begin{array}{l}\text { G2, G3, and G4 dendrimers successfully complexed } \\
\text { the siRNA. G3 and G4 dendrimers showed toxicity } \\
\text { in primary neurons only at high concentrations and } \\
\text { G2 showed none. } \\
\text { G3 and G4 dendrimers were taken up in C6 cell } \\
\text { line for p42-MAPK siRNA delivery. }\end{array}$ & $\begin{array}{l}\text { [In vitro] LDH } \\
\text { release }\end{array}$ & $\begin{array}{l}\text { [In vitro] Rhodamine } \\
\text { fluorescence microscopy }\end{array}$ \\
\hline Uram et al $(2017)^{63}$ & $\begin{array}{l}\text { Biotin } \\
\text { Pyridoxal }\end{array}$ & $\begin{array}{l}\text { U-118 } \\
\text { SCC-15 }\end{array}$ & $\begin{array}{l}\text { Increased cellular uptake of biotinylated G3 } \\
\text { PAMAM dendrimers for up to } 24 \text { hrs of incubation. } \\
\text { Cell viability of U-I I 8-MG cells reduced with high } \\
\text { sensitivity using biotinylated G3 PAMAM } \\
\text { dendrimers with lower normal cell cytotoxicity. }\end{array}$ & $\begin{array}{l}\text { [In vitro] neutral red } \\
\text { lysosomal stability } \\
\text { assay \& XTT assay }\end{array}$ & $\begin{array}{l}\text { [In vitro] FITC confocal } \\
\text { microscopy }\end{array}$ \\
\hline Jiang et al $(2016)^{75}$ & $\begin{array}{l}\text { Pep-I (glioma homing } \\
\text { peptides) }\end{array}$ & U87MG & $\begin{array}{l}\text { PEGylated PAMAM dendrimers conjugated with } \\
\text { glioma homing peptide (Pep-I) for targeting } \\
\text { U87MG cells in vitro and U87MG tumor-bearing } \\
\text { mice in vivo. } \\
\text { Pep-I conjugated dendrimers were not cytotoxic } \\
\text { to U87MG cells in vitro but was localized within } \\
\text { U87MG cell lysosomes. Dendrimer construct } \\
\text { accumulated in the tumor within tumor-bearing } \\
\text { mice. }\end{array}$ & [In vitro] MTT assay & $\begin{array}{l}\text { [In vitro] FITC } \\
\text { fluorescence microscopy } \\
\text { [In vivo] FITC \& Cy5.5 } \\
\text { fluorescence microscopy }\end{array}$ \\
\hline Zhang et al $(2015)^{74}$ & $\begin{array}{l}\text { Fibrin-binding peptide } \\
\text { CREKA }\end{array}$ & $9 \mathrm{~L}$ & $\begin{array}{l}\text { G4 PAMAM dendrimers delivered intracranially for } \\
\text { rodent gliosarcoma. Dendrimers distributed } \\
\text { throughout tumor within } 15 \text { mins with high } \\
\text { permeation and perfusion. Dendrimers cleared at } \\
\text { a rate of } 0.01 \mu g / g / h r \text { and accumulated in the renal } \\
\text { cortex. }\end{array}$ & N/A & $\begin{array}{l}\text { [In vivo] FITC \& Cy5.5 } \\
\text { fluorescence }\end{array}$ \\
\hline Zhao et al $(2015)^{76}$ & $\begin{array}{l}\text { Fibrin-binding } \\
\text { CREKA }\end{array}$ & U87MG & $\begin{array}{l}\text { CREKA-conjugated PEGlyated PAMAM dendrimers } \\
\text { enhanced fibrin binding capacity of dendrimers and } \\
\text { increases uptake into glioma. Nanoparticles also } \\
\text { found in kidney, liver, and spleen. }\end{array}$ & N/A & $\begin{array}{l}\text { [In vitro], [In vivo], \& [ex } \\
\text { vivo] IVIS spectrum } \\
\text { imaging }\end{array}$ \\
\hline Yang et al $(2014)^{88}$ & $\begin{array}{l}\text { Epirubicin } \\
\text { Let-7g miRNA }\end{array}$ & U87MG & $\begin{array}{l}\text { PAMAM dendrimers conjugated with Gd-NGO } \\
\text { carried epirubicin and Let-7g miRNA which } \\
\text { inhibited cancer cell growth and showed efficient } \\
\text { transfection. }\end{array}$ & $\begin{array}{l}\text { [In vivo] FAM- } \\
\text { labelled fluorescence } \\
\text { microscopy }\end{array}$ & $\begin{array}{l}\text { [In vivo] FAM -labelled } \\
\text { fluorescence microscopy }\end{array}$ \\
\hline
\end{tabular}

(Continued) 
Table 2 (Continued).

\begin{tabular}{|l|l|l|l|l|}
\hline Investigators & Cytotoxic Cargo & $\begin{array}{l}\text { Cell } \\
\text { Lines }\end{array}$ & Results & $\begin{array}{l}\text { Cell Viability } \\
\text { Measurement }\end{array}$ \\
\hline Yan et al $(201 \mathrm{l})^{54}$ & $\begin{array}{l}\text { Tumor vasculature } \\
\text { targeted cyclic } \\
\text { peptides } \\
\text { BBB-permeable } \\
\text { angiopep-2 peptides }\end{array}$ & U87MG & $\begin{array}{l}\text { G5 PAMAM dendrimers packaged with peptides } \\
\text { target integrin on tumor vasculature and LRP } \\
\text { receptors on vascular endothelial cells and tumor } \\
\text { cells for targeting U87MG GB cells. }\end{array}$ & $\begin{array}{l}\text { [In vitro] MTT assay } \\
\text { [In vitro] \& [In vivo] } \\
\text { Den-RGD-Angio } \\
\text { fluorescence microscopy }\end{array}$ \\
\hline Ofek et al $(2010)^{56}$ & $\begin{array}{l}\text { Luciferase siRNA } \\
\text { U87MG }\end{array}$ & $\begin{array}{l}\text { PEI-PAMAM dendrimers delivered luciferase siRNA } \\
\text { to silence luciferase gene expression in U87MG } \\
\text { cancer cells with high efficacy and low cytotoxicity. }\end{array}$ & [In vitro] XTT assay & $\begin{array}{l}\text { [In vivo] } \\
\text { Bioluminescence imaging } \\
\text { with mCherry and FITC- } \\
\text { labelled luciferase siRNA }\end{array}$ \\
\hline
\end{tabular}

latter resulted in significantly higher cellular expression of apoptin compared to the former, suggesting that surface modifications with FHR may enhance gene transfer into glioma cells. $^{60}$

While surface modifications to PAMAM dendrimers influence the cell-specificity of the dendrimers, they can also enhance cargo delivery. For instance, at Central Michigan University, a G4 PAMAM dendrimer with a cystamine core (D-Cys) with a 90:10 surface ratio of hydroxyl to amine has been developed to encapsulate curcumin (Cur) ${ }^{61}$ This ratio creates an overall positive charge with less cationic density compared to the pure amine surface dendrimers to facilitate cell entry. Furthermore, Cur and the cystamine core possess the antiinflammatory and anti-tumorigenic properties important for GB growth suppression. While Cur is normally metabolized rapidly in the liver and has poor solubility and bioavailability, encapsulating it inside the cavities of the dendrimer stabilizes the release, increases solubility and stability, and allows it to cross the BBB in therapeutic quantities. $^{61}$

Surface modifications can also involve more complex components such as cyclic compounds. For instance, Qiu and colleagues (2018) used a $\beta$-cyclodextrin (CD)modified, gold $(\mathrm{Au})$-entrapped dendrimer (DENP) to deliver small interfering RNA (siRNA) to GB cells. ${ }^{62}$ These amine-terminated $\left(\mathrm{NH}_{2}\right)$ G5 PAMAM dendrimers were partially grafted with $\beta-\mathrm{CD}$ as a nanoreactor to entrap $\mathrm{Au}$ nanomolecules and were complexed with either B-cell lymphoma/leukemia-2 (Bcl-2) siRNA or vascular endothelial growth factor (VEGF) siRNA. The $\beta$-CD moiety, a cyclic oligosaccharide, functioned to facilitate the release of plasmid DNA (pDNA) or siRNA complex from endosomes after endocytic uptake of the dendrimer. Uptake of the siRNA by cancer cells was measured and results demonstrated that for both Bcl-2 siRNA and VEGFsiRNA polyplexes, the uptake of the vector polyplex was higher when packaged in the $\beta$-CD-modified dendrimer versus the non-modified dendrimer. Moreover, Bcl2 and VEGF protein expression were successfully decreased in cells treated with the dendrimer-delivered siRNA polyplexes with protein expression decreased most in cells treated with the $\beta$-CD-modified dendrimer. Au was utilized to compensate for the dendrimer terminal amine cytotoxicity by reducing the density of amine groups and improve cytocompatibility of the dendrimers. Moreover, it helped maintain the globular conformation of the dendrimer to enhance compaction of the siRNA. ${ }^{62}$

While $\beta-C D$ offers an excellent and highly specific mode of targeted cancer therapy, Uram and colleagues (2017) examined the use of folate and biotin as another potential surface modification for cell-specific targeting. ${ }^{63}$ Cancer therapy research often examines the use of folate and biotin due to overexpression of folate-binding protein and increased biotin receptors in cancer cell membranes for the rapid and uncontrolled proliferation of cancer cells. Given this principle, Uram and colleagues (2017) used G3 PAMAM dendrimers functionalized with four biotin equivalents attached to the amine shell. ${ }^{63}$ Biotinylated bioconjugates are known to have lower cytotoxicity and 3-4 times higher cellular uptake than non-biotinylated dendrimer conjugates. This is important as unmodified PAMAM dendrimers are known to be cytotoxic and increase in cytotoxicity with increased size and cationic character of their surface. ${ }^{64}$

Similar to Qiu and colleagues (2018), Uram and colleagues (2017) found increased uptake of biotinconjugated dendrimers compared to non-conjugated 
Table 3 Summary of All Investigations for Treatment of Glioblastoma with PAMAM Dendrimer Technology - Inhibition of GB Growth and Proliferation

\begin{tabular}{|c|c|c|c|c|c|}
\hline Investigators & $\begin{array}{l}\text { Cytotoxic } \\
\text { Cargo }\end{array}$ & $\begin{array}{l}\text { Cell } \\
\text { Lines }\end{array}$ & Results & $\begin{array}{l}\text { Cell Viability } \\
\text { Measurement }\end{array}$ & $\begin{array}{l}\text { Distribution } \\
\text { Analyses }\end{array}$ \\
\hline $\begin{array}{l}\text { Singh et al } \\
(2019)^{59}\end{array}$ & Docetaxel & $\begin{array}{l}\text { U87MG } \\
\text { GL26I }\end{array}$ & $\begin{array}{l}\text { Hybrid dendrimer (G4-G3.5) constructs conjugated with docetaxel were } \\
\text { increasingly toxic to U87MGMG cells at high concentrations, non-toxic to } \\
\text { control cells, and stable in storage over } 180 \text { days. }\end{array}$ & $\begin{array}{l}\text { [In vitro] MTT assay } \\
\& \text { flow cytometry }\end{array}$ & N/A \\
\hline $\begin{array}{l}\text { Munro et al } \\
(2019)^{61}\end{array}$ & Curcumin & GL26I & $\begin{array}{l}\text { D-Cys-Cur and D-Cys transfection of GL26I cells demonstrated similar anti- } \\
\text { inflammatory properties. Treatment with both complexes in mice equally } \\
\text { prolonged mouse lifespan. No difference in mouse tumor sizes were found } \\
\text { between treatment groups. }\end{array}$ & [In vitro] MTT assay & N/A \\
\hline $\begin{array}{l}\text { Wu et al } \\
(2018)^{77}\end{array}$ & CMBP & U87MG & $\begin{array}{l}\text { MET-targeting cMBP peptides (Den-cMBP } 10 \text { ) conjugated to } G 4 \text { dendrimers } \\
\text { showed inhibition of U87MG cell proliferation with reduced pMET, pAKT, } \\
\text { and pERKI/2 expression levels. } \\
\text { Glioma volume size decreased significantly with Den-cMBP } 10 \text { and median } \\
\text { mouse survival increased by } 59 \% \text {. }\end{array}$ & $\begin{array}{l}\text { [In vitro] TUNEL } \\
\text { assay }\end{array}$ & [In vivo] MRI \\
\hline $\begin{array}{l}\text { Uram et al } \\
(2018 \\
2019)^{78,79}\end{array}$ & $\begin{array}{l}\text { Celecoxib } \\
\text { Fmoc-L- } \\
\text { Leucine }\end{array}$ & $\begin{array}{l}\text { U-I18 } \\
\text { SCC-15 } \\
\mathrm{HaCaT}\end{array}$ & $\begin{array}{l}\text { Conjugated dendrimer delivery of both celecoxib and Fmoc-L-Leucine at } \\
\text { a ratio of } I: I \text { showed significant cytotoxicity in } U-1 / 8 \text { cells. } \\
\text { Decreased cell viability, mobility, and proliferation in U-II8 cells with } \\
\text { administration of a lower dose of G3-BCL }(I-2 \mu \mathrm{M})\end{array}$ & $\begin{array}{l}\text { [In vitro] NR assay } \\
{[\text { In vitro] Apo- }} \\
\mathrm{ONE}^{\circledR} \text { Homogenous } \\
\text { Caspase-3/7 Assay }\end{array}$ & $\begin{array}{l}\text { [ln vitro] } \\
\text { Fluorescence } \\
\text { confocal } \\
\text { microscopy }\end{array}$ \\
\hline $\begin{array}{l}\text { Choi et al } \\
(2017)^{66}\end{array}$ & $\begin{array}{l}\text { Quercetin } \\
\text { Acetazolamide }\end{array}$ & U25I & $\begin{array}{l}\text { Quercetin conjugated PEG-PLGA micelles induced minimal cell death and } \\
\text { reduced nitric oxide release. } \\
\text { Acetazolamide conjugated PEG-PLGA micelles showed increased cell death. }\end{array}$ & $\begin{array}{l}\text { [In vitro] Hoechst } \\
\text { stain \& spheroid } \\
\text { cultures }\end{array}$ & $\begin{array}{l}\text { [In vitro] UV- } \\
\text { absorbance } \\
\text { spectrometry }\end{array}$ \\
\hline $\begin{array}{l}\text { Bae et al } \\
(2017)^{71}\end{array}$ & Apoptin & U87MG & $\begin{array}{l}\text { PAMAM-H-R and PAMAM-H-K showed increased transfection efficiency } \\
\text { compared to PAMAM. } \\
\text { Decreased cell cytotoxicity with PAMAM-H-R/PJDK-apoptin use and greater } \\
\text { apoptosis induction and loss of mitochondrial membrane potential than } \\
\text { PAMAM-H-K/PJDK-apoptin. }\end{array}$ & $\begin{array}{l}\text { [In vitro] EZ-Cytox } \\
\text { cell viability assay, } \\
\text { Caspase } 3 \text { activity } \\
\text { assay, \& cell cycle } \\
\text { distribution }\end{array}$ & $\begin{array}{l}\text { [ln vitro] flow } \\
\text { cytometry \& } \\
\text { fluorescence } \\
\text { confocal } \\
\text { microscopy }\end{array}$ \\
\hline $\begin{array}{l}\text { Pedro- } \\
\text { Hernandez } \\
\text { et al }(2017)^{72}\end{array}$ & Ibuprofen & $\begin{array}{l}\text { U25I } \\
\text { PC-3 } \\
\text { K-562 } \\
\text { HCT-15 } \\
\text { MCF-7 } \\
\text { SKLU-7 } \\
\text { MDA- } \\
\text { MB-23I }\end{array}$ & $\begin{array}{l}\text { Ibuprofen conjugated to the resorcinarene-PAMAM dendrimers resulted in } \\
\text { high inhibition of cell growth and cytotoxicity in all cell lines. } \\
\text { Dendrimer conjugation and modification potency: ethylphenyl group with } 16 \\
\text { ibuprofen moieties > dodecyl group with } 16 \text { ibuprofen moieties > dodecyl } \\
\text { group with } 8 \text { ibuprofen moieties > ethylphenyl group with } 8 \text { ibuprofen } \\
\text { moieties. }\end{array}$ & $\begin{array}{l}\text { [In vitro] Protein- } \\
\text { binding dye } \\
\text { sulforhodamine } \\
\text { B cytotoxic assay }\end{array}$ & $\begin{array}{l}\text { [In vitro] } \\
\text { hydrolysis } \\
\text { release } \\
\text { analysis \& } \\
\text { fluorescence } \\
\text { microscopy }\end{array}$ \\
\hline $\begin{array}{l}\text { Janiszewska } \\
\text { et al }(2016)^{73}\end{array}$ & siRNA & $\begin{array}{l}\text { U87MG } \\
\text { C6 }\end{array}$ & $\begin{array}{l}\text { PLL dendrimers protect siRNA from degradation and inhibited cell } \\
\text { proliferation of GB cell lines; PLL dendrimers mediate cell toxicity with ROS } \\
\text { production after } 24 \text { hrs with mitochondrial depolarization to inhibit GB cell } \\
\text { proliferation. }\end{array}$ & $N / A$ & $\begin{array}{l}\text { [ln vitro] } \\
\text { fluorescence } \\
\text { microscopy }\end{array}$ \\
\hline $\begin{array}{l}\text { Bae et al } \\
(2016)^{70}\end{array}$ & Apoptin & $\begin{array}{l}\text { GBL-14 } \\
\text { GBL-37 }\end{array}$ & $\begin{array}{l}\text { PAMAM-H-R shows better transfection efficiency and higher expression of } \\
\text { apoptin vs PAMAM and PAMAM-H-K dendrimers. } \\
36 \mathrm{hr} \text { transfection in tumor cells with PAMAM-H-R/pJDK-apoptin resulted in } \\
\text { cell death and no apoptosis in dermal fibroblasts with loss of mitochondrial } \\
\text { membrane potential and depletion of cell glutathione levels. }\end{array}$ & $\begin{array}{l}\text { [In vitro] EZ-Cytox } \\
\text { cell viability assay } \\
\text { kit, LDH assay, \& } \\
\text { glutathione assay }\end{array}$ & $\begin{array}{l}\text { [ln vitro] } \\
\text { confocal } \\
\text { microscopy \& } \\
\text { FACS }\end{array}$ \\
\hline $\begin{array}{l}\text { Lesniak et al } \\
(2016)^{90}\end{array}$ & Salicylic acid & U87MG & $\begin{array}{l}\text { G5 PAMAM dendrimers conjugated to salicylic acid delivered to U87MG GB- } \\
\text { bearing mice. } \\
\text { CEST and MRI imaging showed } 50 \% \text { of the tumor images contained the G5 } \\
\text { dendrimer construct. }\end{array}$ & N/A & $\begin{array}{l}\text { [ln vivo] } \\
\text { chemical } \\
\text { exchange } \\
\text { saturation } \\
\text { transfer } \\
\text { (CEST) MRI }\end{array}$ \\
\hline
\end{tabular}

(Continued) 
Table 3 (Continued).

\begin{tabular}{|c|c|c|c|c|c|}
\hline Investigators & $\begin{array}{l}\text { Cytotoxic } \\
\text { Cargo }\end{array}$ & $\begin{array}{l}\text { Cell } \\
\text { Lines }\end{array}$ & Results & $\begin{array}{l}\text { Cell Viability } \\
\text { Measurement }\end{array}$ & $\begin{array}{l}\text { Distribution } \\
\text { Analyses }\end{array}$ \\
\hline $\begin{array}{l}\text { Bai et al } \\
(2013)^{89}\end{array}$ & IFN- $\beta$ & U87MG & $\begin{array}{l}\text { G4 PAMAM-R/pORF dendrimers packaged with IFN- } \beta \text { inhibited cancer cell } \\
\text { growth in vitro by } 27 \% \text {. Xenografts of cancer cells with dendrimer construct } \\
\text { inhibited cancer cell growth. }\end{array}$ & $\begin{array}{l}\text { [In vitro] MTT assay } \\
{[\text { In vivo] TUNEL }} \\
\text { assay }\end{array}$ & $\begin{array}{l}\text { [In vitro] } \\
\text { ELISA (GFP } \\
\text { and luciferase) }\end{array}$ \\
\hline $\begin{array}{l}\text { Perez et al } \\
(2011)^{34}\end{array}$ & siRNA & $\begin{array}{l}\text { T98G } \\
\text { J774 }\end{array}$ & $\begin{array}{l}\text { G7 dendrimers packaged with siRNA administered with an endocytotic } \\
\text { inhibitor. Dendriplexes were taken up by clathrin-dependent endocytosis and } \\
\text { caveolin-mediated endocytosis in J774 cells and by cholesterol, caveolin, and } \\
\text { actin cytoskeleton pathways in T98G cells. }\end{array}$ & $\mathrm{N} / \mathrm{A}$ & $\begin{array}{l}\text { [In vitro] } \\
\text { Trypan blue } \\
\text { and FITC- } \\
\text { labelled } \\
\text { fluorescence } \\
\text { microscopy }\end{array}$ \\
\hline $\begin{array}{l}\text { Ren et al } \\
(2010)^{55}\end{array}$ & $\begin{array}{l}\text { Taxol } \\
\text { miR-2I } \\
\text { inhibitor }\end{array}$ & U25I & $\begin{array}{l}\text { PAMAM dendrimers packaged with taxol and miR-2I inhibitors enhanced cell } \\
\text { apoptosis in U25I and LN229 (control) cells. }\end{array}$ & $\begin{array}{l}\text { [In vitro] MTT assay } \\
\text { [In vivo] annexin V/ } \\
\text { PI staining and flow } \\
\text { cytometry }\end{array}$ & $\begin{array}{l}\text { [ln vitro] } \\
\text { microscopy of } \\
\text { transwell } \\
\text { chambers }\end{array}$ \\
\hline $\begin{array}{l}\text { McNerny et al } \\
(2009)^{57}\end{array}$ & Methotrexate & $\begin{array}{l}\text { U87MG } \\
\text { HUVEC }\end{array}$ & $\begin{array}{l}\text { PAMAM dendrimers conjugated with } c(\text { RGDyK) packaged with } \\
\text { methotrexate inhibited tumor growth in vitro. }\end{array}$ & [In vitro] XTT assay & $\begin{array}{l}\text { [In vitro] flow } \\
\text { cytometry } \\
\text { [In vivo] } \\
\text { confocal } \\
\text { microscopy }\end{array}$ \\
\hline $\begin{array}{l}\text { Kaneshiro } \\
\text { et al }(2009)^{58}\end{array}$ & $\begin{array}{l}\text { Doxorubicin } \\
\text { Luciferase } \\
\text { siRNA }\end{array}$ & U87MG & $\begin{array}{l}\text { G3 Poly(L-lysine) dendrimers with a silsesquioxane cubic core and c(RGDfK) } \\
\text { conjugate were packaged with doxorubicin and siRNA. Successfully inhibited } \\
\text { U87MG-Luc cell growth from doxorubicin-induced cytotoxicity and siRNA } \\
\text { effects. }\end{array}$ & [In vitro] MTT assay & $\begin{array}{l}\text { [In vitro] Cy3- } \\
\text { siRNA } \\
\text { confocal } \\
\text { microscopy }\end{array}$ \\
\hline
\end{tabular}

dendrimers. ${ }^{62,63}$ This increased with incubation time and reached a steady state within the cells after 24 and $48 \mathrm{hrs}$ at low and high concentrations, respectively. ${ }^{63}$ Conjugated dendrimers also had lower cytotoxicity in normal fibroblasts and SCC-15 (squamous cell carcinoma) cancer cell line with higher cytotoxic effects in U-118MG (human glioblastoma) cell lines. Moreover, cancer cell lines also had higher rates of cellular uptake of the biotin-conjugated dendrimers throughout the $24 \mathrm{hrs}$ of incubation. However, the U-118MG cells had the highest sensitivity to conjugated dendrimers and reduced cell viability below $40 \%$ at a given concentration. Overall, the biotinylated conjugated G3 PAMAM dendrimers were less cytotoxic compared to the unconjugated dendrimers and had significantly greater cellular uptake into cancer cells. ${ }^{63}$

The ability to manipulate the net charge and properties of PAMAM dendrimers through surface modification and conjugation allows them to serve as both a delivery system and a therapeutic itself. While DNA and siRNA are often conjugated to the surface of PAMAM dendrimers, other common biomolecules that are utilized are ligands, peptides, PEG, antibodies, antioxidants, and plasmids (Figure 2).
Modifications to dendrimers are not only limited to the shell but may involve changes to the core as well. For instance, Stenström and colleagues (2018) investigated the use of a polyester core in various generations of dendrimers. ${ }^{65}$ These esters are formulated from 2,2-bis(methylol)propionic acid (bis-MPA) and their prior experiments demonstrated rapid degradation of these core-modified dendrimers at physiological $\mathrm{pH}$ and temperature with low cytotoxicity. ${ }^{65} \mathrm{Using}$ G1-G4 polyester core-modified dendrimers they investigated the efficacy of delivering siRNA targeting p42-MAPK (mitogen-activated protein kinase) in C6 and U87MG cell lines. Initial experiments in dendrimer complexion with siRNA found that G1 dendrimers were unsuccessful in integrating the cargo while G2-G4 were successful and utilized for later analyses. G2 dendrimers showed no cytotoxicity at any concentration tested whereas cytotoxicity of G3 and G4 dendrimers were dose-dependent (ie, cytotoxicity reached upwards of $60 \%$ at the highest concentration of G4 dendrimer). Moreover, transfection of G3 and G4 dendrimers into the cytoplasm of $\mathrm{C} 6$ and U87MG cells was observed with a corresponding $20 \%$ decrease in $\mathrm{p} 42-\mathrm{MAPK}$ protein expression in C6 cells, indicating successful transport of the siRNA into tumor cells. ${ }^{65}$ 


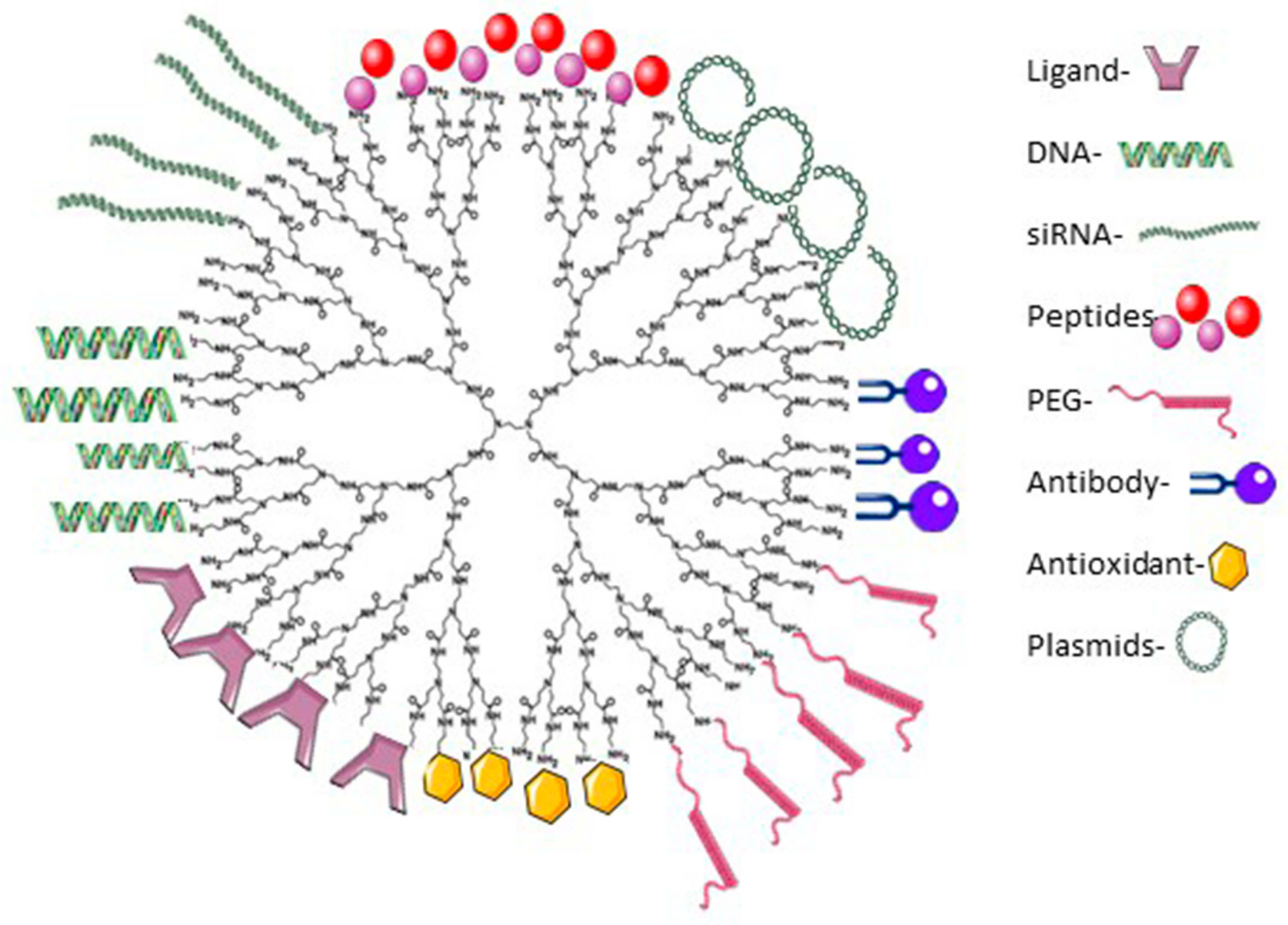

Figure 2 A representation of G4-PAMAM-NH2 dendrimer depicting some possible surface modifications on their surface (figure not to scale). Note: Adapted from Materials Today, I8(10), Kesharwani P, Banerjee S, Gupta U, et al, PAMAM dendrimers as promising nanocarriers for RNAi therapeutics, 565-572, Copyright (2015), with permission from Elsevier. ${ }^{91}$

Dendrimer shapes can vary according to the size and surface charges of the nanomolecules. However, some structures may be formed as a linear construct while others, such as those by Choi and colleagues (2017), can be a hybrid. ${ }^{66}$ Unlike the surface modifications previously described, they formulated a linear-dendrimer block copolymer hybrid called telodendrimers; commercial linear poly(ethylene glycol)-poly-(lactic-co-glycolic acid) (PEGPLGA) used as the surface modification to the classical spherical PAMAM dendrimers. These are hybrid systems that incorporate linear and hyperbranched architectures for a novel nano-structural delivery of drugs that are either covalently bound or physically entrapped. The PEG conjugation has been shown to prolong circulation time of the dendrimer as well as reduce their side effects. ${ }^{67-69}$ Quercetin, a plant-derived bioactive flavonoid and antioxidant found in fruits and vegetables was entrapped in this hybrid dendrimer for transport. Quercetin has therapeutic potential as a pleiotropic kinase inhibitor with antiinflammatory, anti-cancer, anti-obesity, and anti-allergic effects. In cancer cells, it inhibits nuclear translocation of NF-KB, but its low bioavailability and water solubility require micellar delivery. Temozolomide was also added in the telodendrimers to suppress carbonic anhydrase IX and II which are often highly expressed in GB cells. ${ }^{66}$

Choi et al (2017) found that without nanocarrier delivery to U251 GB cells, quercetin was $50 \%$ more effective in cell death induction when compared at equimolar concentrations to temozolomide. ${ }^{66} \mathrm{~GB}$ spheroid cell death was also analyzed with quercetin for 1, 3, and 7 days and cell death was observed to peak at three days. However, with quercetin physically entrapped in the linear-conjugated telodendrimers, there was a significant increase in cancer cell death. Likewise, there was a 7-fold increase in GB cell death in U251 spheroids when acetazolamide is encapsulated in telodendrimers compared to free acetazolamide. ${ }^{66}$ 
Modifications to dendrimers can be as complex as linear-spherical dendrimer hybrids, while others focus simply on altering the amino acid surface profile. For instance, Bae and colleagues (2016) developed a combination of histidine and arginine or histidine and lysine surface amine modification of PAMAM dendrimers. ${ }^{70}$ They developed these dendrimers for delivery of the apoptin gene to glioma cells (GBL-14 cells) and dermal fibroblasts. Apoptin is a 14$\mathrm{kDa}$ basic proline-rich protein containing signals for nuclear localization and export. It induces apoptosis exclusively in a variety of tumor cells. It localizes to the nucleus of tumor and carcinogenic cells but remains in the cytoplasm in primary cells. The dendrimer-apoptin polyplex was formed between the amine of the dendrimer and the anionic phosphate moiety of the DNA backbone. The complexes formed were PAMAM, PAMAM-H-K, and PAMAM-H-R with either pJDK or pJDK-apoptin. The native dendrimer was found to be more cytotoxic than PAMAM-H-R and PAMAM-H-K in GBL-37 cells, whereas in GBL-14 and dermal fibroblasts, the polyplexes did not affect cell viability. Moreover, transfection efficiency was improved with PAMAM-H-R compared to native PAMAM. While both GBL-14 and dermal fibroblasts expressed apoptin after transfection with native PAMAM, PAMAM-H-K, and PAMAM-H-R, the highest expression was found to be in the PAMAM-H-R polyplex. Accordingly, transfection with the PAMAM-H-R pJDK-apoptin complex after 36 hrs demonstrated increased apoptosis in GBL-14 but not dermal fibroblasts. ${ }^{70}$ These results suggest excellent utility in histidine and arginine surface modification to PAMAM dendrimers for efficient delivery of the apoptin gene to glioma cells with lower cytotoxicity compared to native PAMAM dendrimers. ${ }^{70}$

In a follow-up investigation, Bae and colleagues (2017) once again utilized the PAMAM-H-R and PAMAM$\mathrm{H}-\mathrm{K}$ dendrimers to deliver apoptin to U87MG human glioblastoma cells and newborn human dermal fibroblast cells (NB-HDF). ${ }^{71}$ Both cell lines were transfected with one of the following complexes: native PAMAM pJDK, PAMAM-R pJDK, PAMAM-H-R pJDK, or PAMAMH-K pJDK, either with or without the apoptin gene cargo. Levels of apoptin gene expression were significantly high in cells treated with apoptin complexed inside all dendrimer complexes carrying the gene. Moreover, apoptin expression was localized to the nucleus of U87MG cells and in the cytoplasm of NB-HDF cells as expected. U87MG cells were found to be more sensitive and had significantly greater loss of mitochondrial membrane potential with PAMAM-H-R/pJDK-apoptininduced caspase 3 apoptosis than PAMAM-H-K, indicating that the anti-cancer activity is due to decreased mitochondrial membrane potential and increased caspase 3 activity in cancer cells. ${ }^{71}$ Altogether, their experiments have demonstrated that the PAMAM-H-R/pJDK-apoptin complex has negligible levels of cytotoxicity, enhanced transfection efficiency, cellular uptake, and ability to induce apoptosis via mitochondrial-dependent pathways in U87MG cells, indicating an efficacious delivery system with the H-R-surface modification to the PAMAM dendrimer. ${ }^{71}$

Another novel surface modification developed by Pedro-Hernandez and colleagues (2017) utilized ethylphenyl or dodecyl alkyl PAMAM conjugation for delivery of ibuprofen. ${ }^{72}$ Specifically, G1 and G2-modified PAMAM dendrimers were synthesized with either 8 or 16 ibuprofen moieties and applied to human glioblastoma, prostatic adenocarcinoma, mammary adenocarcinoma, and lung adenocarcinoma cell lines. Ibuprofen release from G1modified dendrimers was approximately $65-68 \%$ whereas G2-modified dendrimers was $76-80 \%$. In vitro cell uptake of ibuprofen in PC-3 cells was confirmed after incubation with ibuprofen-carrying dendrimers. However, modified dendrimers were also found to be cytotoxic to PC-3 cells and showed changes in morphology with an increase in cell volume, resulting in round and detached cells. Free ibuprofen was cytotoxic in the U251, K-562, HCT-15, and SKLU-1 cell lines. Once conjugated to the G1-modified dendrimer, in vitro analyses found significant cell growth inhibition in the PC-3, MCF-7-7, and MDA-MB-231 cell lines, whereas with G2-modified dendrimers, cell growth inhibition was $100 \%$ in all cell lines. Moreover, U251, K-562, MDA-MB-231, and MCF-7 cell lines were highly sensitive to growth inhibition by dendrimers conjugated with ibuprofen. Their results further showed that the potency of the dendrimer in cancer cell growth suppression was based according to the surface modification (ethylphenyl $>$ dodecyl) and number of ibuprofen moieties $(16>8)$. In particular, both G1 and G2 dendrimers carrying ibuprofen had significant cell death effects in human glioblastoma and human mammary adenocarcinoma cell lines. $^{72}$

Not unlike the previous amino acid surface modifications described thus far, Janiszewska and colleagues (2016) synthesized G2 dendrimers with an amphiphilic poly-L-lysine (PLL) surface modification for carrying siRNA. ${ }^{73}$ The PLL dendrimers were able to completely 
bind siRNA at varying dendrimer:siRNA molar ratios. Uptake of PLL dendrimers was found to both protect siRNA from the RNAse-mediated degradation and help transport siRNA to the interior of both U87MG and C6 glioblastoma cells; the siRNA uptake ranged from $42 \%$ to $51 \%$, with no difference between the two cell lines. Moreover, PLL dendrimers were also found to cause mitochondrial depolarization and increase reactive oxygen species (ROS) production that peaked at $24 \mathrm{hrs}$, resulting in inhibition of GB cell proliferation. ${ }^{73}$

Hydroxylation of the dendrimer terminal is another surface modification that allows for a more tailorable branched macromolecule with a hydrodynamic size small enough and with near-neutral surface charge to cross the BBB and extracellular matrix. This is crucial as the $\mathrm{BBB}$ presents as a natural barrier to therapeutic delivery to intracranial tumors such as GB. As such, improving the dendrimer tumor selectivity is as critical as its focused biodistribution to tumor regions. Zhang and colleagues (2015) investigated this approach to facilitate more rapid uptake of G4 PAMAM dendrimers into GB cells. $^{74}$ Using confocal microscopy, the G4-PAMAM-OH dendrimer was found to accumulate in a 6-mm tumor within 15 mins after intracranial injection into rodent GB while in the healthy contralateral hemisphere, the dendrimer outlined the blood vessels but did not enter the parenchyma. Fifteen minutes after delivery, the dendrimers dispersed throughout the entirety of the tumor. Four hours later, the extracellular distribution in the tumor region decreased with increased inflammatory cells. The concentration in the contralateral hemisphere after $8 \mathrm{hrs}$ was 8 -fold lower than in the tumor area with only traces detected after 24 hrs. Forty-eight hours later, the tumor was 10 times more exposed to the dendrimer than in the contralateral hemisphere. Dendrimers cleared from the tumor at a rate of $0.01 \mu \mathrm{g} / \mathrm{g} / \mathrm{hr}$ and from the peritumoral area at a rate of $0.007 \mu \mathrm{g} / \mathrm{g} / \mathrm{hr}$. Permeation constant $\left(\mathrm{K}_{\mathrm{in}}\right)$ was 10 -fold higher in tumor and peritumoral area compared to the contralateral hemisphere, indicating increased penetration of dendrimers and increased permeability and perfusion of tumor tissue. These results demonstrated the selective and homogenous distribution of the G4-PAMAM-OH dendrimer throughout the solid tumor and peritumoral area just 15 mins after its administration. $^{74}$

\section{Dendrimer Conjugations}

The surface modifications described thus far demonstrate successful alterations to the dendrimer structure that have improved the delivery of the cargo to GB and other cancer cell lines. However, in addition to increasing biodistribution, another crucial aspect to cancer treatment involves specific targeting of cancer cells to reduce cytotoxic effects to noncancers. While Jiang and colleagues (2016) bring to light another frequently used surface modification to the dendrimer (ie, PEG), they also conjugated a peptide to help facilitate increased specificity for cancer cells. ${ }^{75}$ Specifically, gliomahoming peptide (Pep-1) was conjugated to the PEGylated G5 PAMAM dendrimer for a glioma-targeted delivery system (Pep-PEG-PAMAM). ${ }^{75}$ The PEG surface modification in the PAMAM dendrimer prolonged in vivo circulation time and significantly lowered cytotoxicity due to the low reticuloendothelial system recognition. IL-13 plays a role in regulating immune response and the microenvironment. It has an $\alpha-2$ subunit that is overexpressed in glioma cell lines and primary GB cell culture, making it a viable target for glioma therapy. Pep-1, a linear peptide with nine amino acid residues, is a ligand of IL-13 receptor $\alpha-2$ that allows for improved glioma targeting. Jiang and colleagues (2016) utilized both Mal-PEG-PAMAM-FITC (control) and Pep-PEG-PAMAMFITC on U87MG cells and found stronger fluorescent intensity of PAMAM constructs with Pep-1 conjugation compared to those without, suggesting improved targeting of GB cells. ${ }^{75}$ In vivo fluorescence imaging was also performed to evaluate the targeting ability of Pep-PEG-PAMAM-FITC/Cy5.5 (cyanine 5.5) on intracranial U87MG tumor-bearing mice. This dendrimer accumulated significantly more at the tumor site as time progressed from 4 to $24 \mathrm{hrs}$ when compared to Mal-PEGPAMAM-FITC. Finally, fluorescence microscopy showed Pep-PEG-PAMAM distributed well throughout the glioma whereas the Mal-PEG-PAMAM was minimally distributed. Moreover, there was a greater concentration of Pep-PEGPAMAM endocytosed by U87MG cells which was confirmed by in vivo fluorescence imaging of U87MG tumor-bearing mice, suggesting successful homing of Pep-1 to GB cells. ${ }^{75}$

Similar to Jiang et al (2016) use of the Pep-1 tumortargeting peptide, Zhao and colleagues (2015) also developed a tumor-homing peptide conjugate, CREKA, for improving GB penetration and selectivity. ${ }^{75,76}$ This linear pentapeptide is typically used for myocardial ischemiareperfusion. They also utilized the PEGylated surface modification for efficient dendrimer delivery of CREKA. Specifically, CREKA was conjugated to PEGylated G5 PAMAM dendrimers for targeting fibrin in glioblastoma. ${ }^{76}$ In vitro fibrin clot binding with CREKA-PEG-PAMAM was first assessed with fresh frozen plasma (FFP) clots and imaged with an in vivo imaging system (IVIS). The fibrin clots were incubated with CREKA-PEG-PAMAMFITX and showed stronger fluorescence intensity than fibrin 
clots incubated without CREKA, suggesting enhanced fibrin binding capacity of these dendrimers with CREKA conjugation. Imaging using in vivo imaging system of GBbearing mice given PBS, CREKA-PEG-PAMAM-FITX, or Mal-PEG-PAMAM-FITC (control) showed that the CREKA glioma-targeted group had higher fluorescence intensity at the glioma site than that of the control group at 12 and $24 \mathrm{hrs}$, indicating more efficient internalization of these dendrimers. Penetration of glioma with CREKA-PEG -PAMAM-FITC in GB was then examined with fluorescence microscopy. The Mal-PEG distributed sparsely at the edge of the tumor and deep within while CREKAPEG distributed extensively and reached the deeper sections of the tumor. ${ }^{76}$ Their experiments suggest that while the PEG modification can penetrate deep into tumor tissue there is little retention whereas with the additional CREKA conjugation, there is significant improvement in nanomolecule retention in tumor tissue. ${ }^{76}$

Another example of such specific tumor-targeting dendrimer construct is that by $\mathrm{Wu}$ and colleagues (2018). ${ }^{77}$ However, here the intention is not only for tumor-targeting but for suppression of specific tumor protein targets using the dendrimer conjugate as well. Specifically, they conjugated a MET-targeting peptide, cMBP, to G4 PAMAM dendrimers for targeting of U87MG cells in vitro. ${ }^{77}$ MET is a signaling protein responsible for downstream activation of the Ras-MAPK, PI3K-AKT, and Racl-Cdc42 pathways which in turn promote cancer cell proliferation, survival, and invasion, making it not only ideal for tumor targeting but for protein-targeted therapeutic intervention as well. Targeting of MET was made possible with cMBP peptides (either 5 or 10) conjugated to the G4 PAMAM dendrimer with PEG linkers (Den-cMBP 10 and Den$\mathrm{cMBP}_{5}$ ). Light microscopy of the U87MG cells incubated with Den-cMBP 10 for $24 \mathrm{hrs}$ showed cell death with shrinkage and plate detachment in nearly all tumor cells. Increasing concentrations of the Den-cMBP 10 were also linked to increased cytotoxicity in U87MG cells but not in normal rat astrocytes. Immunoblot assays further demonstrated significant reduction in phosphorylated MET, AKT, and ERK1/2 in U87MG cells treated with Den-cMBP ${ }_{10}$, whereas normal rat astrocytes demonstrated no significant changes. ${ }^{77}$ These results demonstrated the successful targeting and inhibition of the U87MG cell over-activation of the MET signaling pathway, which could translate in future research to decrease cancer cell proliferation. ${ }^{77}$

In addition to these findings, in vivo results further showed similar promising findings. MR images collected at 7, 15, and 21 days after intravenous administration of Den-cMBP 10 in mice that were xenografted with U87MG cells resulted in a significant decrease in tumor volume by 76. 7-86.6\% compared to controls. Moreover, median mouse survival with tumor xenograft was 22 days, while mice treated with Den-cMBP ${ }_{10}$ was 35 days, indicating an increase in survival by $59 \%$. As with the in vitro studies, $p$ MET levels in the xenografted mice after intravenous administration of Den-cMBP ${ }_{10}$ was reduced by $62.3 \%$ compared to control. Likewise, expression levels of $p$ AKT and $p$ ERK $1 / 2$ were also significantly reduced. Clearly, targeting of specific intracellular proteins responsible for the growth and progression of cancer cells provides an excellent avenue for investigators to explore viable therapeutic inhibitors. Furthermore, as demonstrated in this investigation and many others, these unique protein targets are also quite often markedly elevated in expression beyond what is normal in non-cancerous cells, making them excellent targets for dendrimers to deliver the appropriate intervention. ${ }^{77}$

Like $\mathrm{Wu}$ and colleagues (2018), Uram and colleagues $(2018,2019)$ investigated two upregulated tumor protein targets for developing an appropriate inhibitor and cancer cell-targeting dendrimer. ${ }^{77-79}$ Specifically, various cancer cell lines, including GB, are known to overexpress cyclooxygenase-2 (COX-2) and peroxisome proliferator-activated receptor $\mathrm{y}$ (PPARy) proteins. ${ }^{78} \mathrm{COX}-2$ has been shown to promote proliferation, migration, and invasion of cancer cells, resist apoptosis, and stimulate angiogenesis. Conversely, PPARy has been shown in in vitro studies to promote growth inhibition, apoptosis, cell cycle arrest, and re-differentiation of a malignant cell line. ${ }^{80-82}$ As a result, both substrates provide an opportunity for cancer cell targeting and inhibition of growth and development by way of inhibition of COX-2 and activation of PPARy. Uram and colleagues (2018) achieved this by utilizing the COX-2 inhibitor, celecoxib, and PPARy agonist, Fmoc-L-Leucine, to conjugate with biotinylated G3 PAMAM dendrimers (G3$\mathrm{BCL}){ }^{78,79}$ In their initial experiments, variable quantities of celecoxib were used per dendrimer construct for administration to glioblastoma and squamous cell carcinoma cell lines. The highest cytotoxicity in U118MG cancer cells was determined to be with a 1:1 combination of Fmoc- ${ }_{\mathrm{L}}$-Leucine and celecoxib-conjugated dendrimer when compared to individual (ie, Fmoc-L-Leucine or celecoxib alone) drugconjugated dendrimers. ${ }^{78}$ In follow-up investigations, a significant decrease in U-118MG cell viability, proliferation, and mobility was found with in vitro administration of 
lower doses (ie, 1-2 $\mu \mathrm{M}$ ) of G3-BCL for a 24-72 hrs therapy compared to celecoxib administration alone. The dendrimer complex was also found to localize primarily in the lysosome and mitochondria of both control and glioma cell lines with subsequent increased caspase $3 / 7$ activity which peaked at 2 $\mu \mathrm{M}$ of G3-BCL administration, indicating apoptosis. ${ }^{79}$ These results are notable with respect to a novel targeting substrate in the treatment of glioblastoma and highlight the utility of dendrimers with multiple conjugated therapeutic agents. Looking ahead, in vivo investigations into the utility of such constructs would further potentiate the promising outlook of such constructs. ${ }^{78}$

\section{Tumor Penetration}

The presence and development of some brain tumors can disrupt the function of the BBB. While in lower-grade gliomas the BBB remains intact and functional, in higher grade gliomas (eg, glioblastoma) there is a major disruption in the vascular function. ${ }^{83}$ As a tumor grows, it continues to develop greater metabolic demands. This triggers an increased expression of vascular endothelial growth factor (VEGF) resulting in rapid angiogenesis and thereby leading to abnormal and dysfunctional vasculature within the blood-brain tumor barrier (BBTB) ${ }^{84}$ While we know disruption occurs, if the level of BBB breakdown is not homogeneous, many glioblastoma patients can still be seen with an intact BBB. ${ }^{85}$ However, it has been shown that chemotherapeutic agents which normally were unable to cross an intact $\mathrm{BBB}$, have been able to reach central areas of the tumor through a disrupted BBTB. ${ }^{86}$ This suggests that it may be possible to take advantage of such a weakened and more permeable BBTB to deliver larger drugs in greater therapeutic amounts.

However, tumor penetration is yet another challenge ahead of therapeutic intervention. While dendrimers can be constructed in ways that allow for increased specificity of cancer cell targeting, penetration of individual cells can be difficult when attempting to deliver larger therapeutic agents. For this reason, Liu and colleagues (2018) developed an acryl G4 PAMAM- $\mathrm{NH}_{2}$ dendrimer conjugated to the cell-penetrating peptide, trans-activating transcriptional (TAT) activator peptide, along with PEG for delivery of the cytotoxic peptide (KLAKLAK) 2 (KLAK). ${ }^{87}$ This conjugated dendrimer, denoted as PKT-S-PEG, was built according to a KLAK:TAT:PEG molar ratio of 50:10:40. KLAK is a peptide that specifically destroys the mitochondrial membrane of cells to elicit the apoptotic cascade for cell destruction. However, it has a large molecular weight with hydrophilic properties which necessitates modifications of the dendrimer construct for appropriate tumor cell delivery. Moreover, the PEG conjugate prevents enzyme degradation of KLAK in the blood to later allow for degradation by MMP-2 secretion from U87MG cells. This would subsequently expose TAT to permit enhanced dendrimer penetration of the cancer cells. As such, application of PKT-S-PEG was found to be significantly more cytotoxic to U87MG cells (cell viability of 40-60\%) compared to control MCF-7 cells (>85\%). PKT-S-PEG efficiently penetrated U87MG cells within $2 \mathrm{hrs}$ of incubation, localized to either the cellular lysosomes or membranes. Incubation of U87MG cells with PKT-S-PEG also resulted in significant destruction of the cellular mitochondria. Finally, depth of tumor penetration with TAT was investigated using multicellular spheroids of the U87MG cells. PKT-S-PEG dendrimers penetrated to a depth of $70-80 \mu \mathrm{m}$ within the tumor with high fluorescence intensity in the tumor interior whereas control dendrimers penetrated down to $30 \mu \mathrm{m}$, only, after an $8 \mathrm{hr}$ incubation. ${ }^{87}$ The investigation by Liu and colleagues (2018) has demonstrated the importance of enhancing tumor penetration as large tumors can be difficult to eradicate effectively without appropriate depth of therapeutic intervention. ${ }^{87}$

\section{Other Therapeutics}

The use of RNA interference (RNAi) constructs and drugs packaged within dendrimers is a promising therapeutic approach for treatment of GB. While siRNAs are commonplace for various gene editing and cancer therapeutics, microRNAs (miRNAs) offer yet another avenue to explore the wide breadth of dendrimer-delivery technology. Yang and colleagues (2014) developed G4 dendrimers modified with gadolinium-functionalized nanographene oxide (Gd-NGO) for delivery of Let-7g miRNA or epirubicin (EPI) to cancer cells (Gd-NGO-Let-7g/EPI) ${ }^{88}$ Nine members of the Let-7 miRNA family have been detected in human tissue. These miRNAs function as tumor suppressors by decreasing expression of the Ras oncogene family. Downregulation of Let-7 has been observed in cancers such as lung, colon, and melanoma. While overexpression of Let-7 has been shown to inhibit cancer cell growth and proliferation. Nanoscale graphene oxide (NGO) is a nanomaterial that is capable of delivering oligonucleotides into cells and protecting them from enzymatic cleavage. Moreover, PEG-functionalized NGO can be loaded with drugs such as doxorubicin and epirubicin. After loading efficiency of Let-7g and EPI onto Gd-NGO was confirmed, release study for Let- $7 \mathrm{~g}$ and EPI found that $15 \%$ 
of EPI was rapidly released from Gd-NGO in the first $18 \mathrm{hrs}$ of incubation at a $\mathrm{pH}$ of 7.4 ; this increased to $41 \%$ in $24 \mathrm{hrs}$ and $57 \%$ after another $60 \mathrm{hrs}$ of incubation. Meanwhile, a 13\% release of Let-7g from Gd-NGO was found at physiological $\mathrm{pH}$ with a $10 \mathrm{hr}$ delayed release, suggesting that Let-7g would not be released from Gd-NGO too early before reaching the targeted cell. Gd-NGO delivery of pDNA and Let-7g into U87MG cells in vitro was confirmed with fluorescence microscopy after $48 \mathrm{hrs}$ and a significant reduction in Ras expression with Gd-NGO/Let-7g and Gd-NGO/EPI was observed. Finally, because Gd-NGO can be used as a contrast agent for MRI to quantify concentration of EPI and Let-7g in the brain, tail vein injections of Gd-NGO/Let-7g confirmed successful transfection of Let- $7 \mathrm{~g}$ into tumor cells $12 \mathrm{hrs}$ after injection. $^{88}$

The unique physical and chemical properties of PAMAM dendrimers allow for many other biochemical compounds, such as cytokines, to be packaged and delivered to target cells as well. For instance, Bai and colleagues (2013) utilized G4 PAMAM dendrimers for delivery of IFN- $\beta$ and similar to Bae and colleagues (2017), they too used an amino acid surface modification. ${ }^{71,89}$ Specifically, they formulated PAMAM dendrimers surface-modified with arginine residues (PAMAM-R) for delivery of PAMAM-R pORF-IFN $\beta$ to mice transfected with U87MG cells. IFN- $\beta$ is an immune gene which exerts anti-tumor activity via induction of apoptosis in tumor cells. Bai and colleagues (2013) found PAMAM-R pORFIFN- $\beta$ inhibited growth of Neuro2A and U87MG cancer cells by $46 \%$ and $27 \%$, respectively, compared to control (PAMAM-R pORF). ${ }^{89}$ Next, after xenografting mice with U87MG, the tumor size after 21 days in controls was between 358.1 and $373.1 \mathrm{~mm}^{3}$ compared to $27.6 \mathrm{~mm}^{3}$ in PAMAM-R pORF-IFN- $\beta$-treated mice, demonstrating significant tumor size reduction. ${ }^{89}$

While surface modifications can enhance dendrimer delivery and tumor specificity, not all investigators utilized or developed a dendrimer modification for successful therapeutic application. In fact, Lesniak and colleagues (2016) utilized a G5 dendrimer for delivery of salicylic acid (G5SA) without any surface modifications. ${ }^{90}$ However, their primary goal was to investigate the utility of a novel in vivo imaging tool and these dendrimer complexes were delivered to U87MG glioblastoma-bearing nude mice. They were then examined with a novel MRI contrast mechanism for imaging using a specific radiolabeling technique. Delivery and distribution of the G5-SA were based on convection-enhanced delivery (CED) which involves pressurized infusion directly into a tumor. SCID mice were inoculated with U87MG GB cells in the right caudate putamen and the dendrimers were delivered at the same site. Infusion sites were followed by their new MRI tool and results found $50 \%$ of the tumor images received contained G5-SA dendrimer conjugates. ${ }^{90}$ As such, while no surface modifications or conjugations were used, the dendrimers were manually targeted into the specific region of which the tumor was originally placed, excluding the need for increasing dendrimer tumor cell localization. ${ }^{90}$

\section{Conclusion}

In this review, we have outlined the historical progression of dendrimer nanomolecule development and its therapeutic application for treating glioblastoma. PAMAM dendrimers were developed in 1985 by Tomalia and since then various types of therapeutic applications have been tested with this technology. There is strong evidence of its therapeutic capabilities and promise in the treatment of GB; it presents the opportunity to load and carry various plasmids, miRNAs, metals, siRNAs, biological molecules, and drugs across the BBB. In fact, its benefits may one day become the treatment option of choice over the conventional treatment options we have today and other nanomolecular options (eg, micelles, viral, etc.). Additionally, when compared to other nanomolecule treatment strategies, dendrimers have shown improved bio-safety profiles, ease of synthesis, target specificity to cells and tissues with surface modifications, structural diversity, and capability of plasmid transfection. Moreover, biopolymer-based nanomolecules such as PAMAM dendrimers have flexibility in structure and are non-toxic, biocompatible, and biodegradable. It is important to bear in mind the physical size limitations of possible therapeutic applications; microvascular pore size of the most commonly tested cell line, U87MG glioma cells, are between 7- and $100 \mathrm{~nm}$. Moreover, it has been shown that the glycocalyx coating of the luminal surface of endothelial cells make the true physiological pore size even smaller than the anatomical pore size. This is important to keep in mind when designing nanomolecules and further supports the use of dendrimers as superior to other nanomolecules.

Glioblastoma is currently theorized to either originate from mature glial cells that undergo mutations in oncogenes or tumor suppressor genes which de-differentiate and develop into a tumor or from progenitor cells that undergo transformation during development. Histologically, malignancy is determined by excess cells, pleomorphy, nuclear atypia, 
uncontrolled cell division, and angiogenesis. Moreover, glioblastoma is frequently accompanied by tumor-associated macrophages. These macrophages promote tumor growth and metastasis by secreting a range of proangiogenic factors, growth factors, metalloproteinases, and suppressors of CD8 $\mathrm{T}$ cells; in fact, a high degree of macrophage infiltration is associated with a poor prognosis. As such, GB is an aggressive brain tumor with poor prognosis and high recurrence rates. Survival times are often less than 15 months for patients and treatment options are limited to open surgery, chemotherapy, and radiotherapy, which are often found to be ineffective in treating the cancer or preventing relapse. Moreover, some glioblastomas are resistant to radiotherapy and chemotherapy and instead compound tumor aggressiveness, increasing the chances of treatment failure. Other barriers to therapy include the BBB which only permit certain small or uncharged substances across. Therefore, new therapeutic options and technologies are necessary to combat the destructive and rapid deterioration of this cancer. Dendrimers offer a clear avenue for which a highly specific targeted therapy may be applied for treatment of glioblastoma. Future development of this technological application and its promising clinical application provide significant hope for realizing an effective treatment for glioblastoma.

\section{Future Prospects}

Many of these early experiments laid the groundwork for GB treatment with dendrimer nanotechnology. The use of miRNA, siRNA, drugs, and other biomolecules described here was utilized throughout the many years of GB therapy. As more research interest was placed into therapeutic strategies, more appropriate surface, size, and core modifications to the dendrimer construct were also developed. For instance, G7 dendrimers are now largely replaced with G3, G4, or G5 dendrimers as the smaller generations allow for greater BBB permeation and cellular uptake. Dendrimer nanotechnology continues to be modified to formulate the precise construct for tumor specificity and permeability, reduced cytotoxicity, and passage across the BBB. In addition, the options for therapeutic cargo delivery are limitless.

\section{Abbreviations}

$\beta$-CD, $\beta$-cyclodextrin; PEG, Poly(ethylene glycol); GdNGO, Gadolinium-functionalized nanographene oxide; PLGA, poly(lactic-co-glycolic acid); TAT, transactivator of transcription; c[RGDyK], cyclic RGD-tyrosine-lysine pentapeptide; GB, glioblastoma; TMZ, temozolomide; BBB, blood-brain barrier; PAMAM, poly(amidoamine); TEA, triethanolamine; DTX, docetaxel; pDNA, plasmid DNA; MTT, 3-(4,5-dimethylthiazol-2-yl)-2,5-diphenyltetrazolium bromide; bis-MPA, 2,2-bis(methylol)propionic acid; MAPK, mitogen-activated protein kinase; PLL, polyL-lysine; PEG, polyethylene glycol; FITC, fluorescein isothiocyanate; TAT, transcriptional activator peptide; MMP, matrix metalloproteinase; IFN- $\beta$, interferon- $\beta$.

\section{Author Contributions}

All authors contributed to data analysis, drafting and revising the article, gave final approval of the version to be published, and agree to be accountable for all aspects of the work.

\section{Funding}

We would like to thank the Program in Neuroscience, the College of Medicine, and the John G. Kulhavi Professorship in Neuroscience at Central Michigan University and the Field Neurosciences Institute.

\section{Disclosure}

The authors report no conflicts of interest in this work.

\section{References}

1. Louis DN, Ohgaki H, Wiestler OD, et al. The 2007 WHO classification of tumors of the central nervous system. Acta Neuropathol. 2007;114(2):97-109. doi:10.1007/s00401-0070243-4

2. Westphal M, Lamszus K. The neurobiology of gliomas: from cell biology to the development of therapeutic approaches. Nat Rev Neurol. 2011;12(9):495-508. doi:10.1038/nrn3060

3. De Paula LB, Primo FL, Tedesco AC. Nanomedicine associated with photodynamic therapy for glioblastoma treatment. Biophys Rev. 2017;9(5):761-773. doi:10.1007/s12551-017-0293-3

4. Agnihotri S, Burrell KE, Wolf A, et al. Glioblastoma, a brief review of history, molecular genetics, animal models and novel therapeutic strategies. AITE. 2013;61:25.

5. Messali A, Villacorta R, Hay JW. A review of the economic burden of glioblastoma and the cost effectiveness of pharmacologic treatments. Pharmacoecon. 2014;32(12):1201. doi:10.1007/ s40273-014-0198-y

6. Delgado-López PD, Corrales-García EM. Survival in glioblastoma: a review on the impact of treatment modalities. Clin Transl Oncol. 2016;18(11):1062-1071. doi:10.1007/s12094-016-1497-x

7. Ostrom QT, Cote DJ, Ascha M, Kruchko C, Barnholtz-Sloan JS. Adult glioma incidence and survival by race or ethnicity in the United States from 2000 to 2014. JAMA Oncol. 2018;4(9):1254. doi:10.1001/jamaoncol.2018.1789

8. Rath G, Mallick S, Gandhi A. Therapeutic approach beyond conventional temozolomide for newly diagnosed glioblastoma: review of the present evidence and future direction. Indian J Med Pediatr Oncol. 2015;36(4):229. doi:10.4103/0971-5851.171543

9. Stupp R, Tonn JC, Brada M, Pentheroudakis G, Group EGW. Highgrade malignant glioma: ESMO clinical practice guidelines for diagnosis, treatment and follow-up. Ann Oncol. 2010;21(5):190-193. doi:10.1093/annonc/mdq187

10. Balakrishnan S, Bhat FA, Jagadeesan A. Applications of gold nanoparticles in cancer. Biomed Eng. 2017;35:780-808. 
11. Lesin VI, Koksharov YA, Khomutov GB. Magnetic nanoparticles in petroleum. Petrol Chem. 2010;50(2):102-105. doi:10.1134/ S0965544110020039

12. Mafuné F, Kohno J, Takeda Y, Kondow T. Nanoscale soldering of metal nanoparticles for construction of higher-order structures. $J \mathrm{Am}$ Chem Soc. 2003;125(7):1686-1687. doi:10.1021/ja021250d

13. Sabir S, Arshad M, Chaudhari SK. Zinc oxide nanoparticles for revolutionizing agriculture: synthesis and applications. Sci World J. 2014;2014:1-8. doi:10.1155/2014/925494

14. Subbiah R, Veerapandian M, Yun KS. Nanoparticles: functionalization and multifunctional applications in biomedical sciences. Curr Med Chem. 2010;17(36):4559-4577. doi:10.2174/0929867107941 83024

15. Farrell HH, Siclen CD. Binding energy, vapor pressure, and melting point of semiconductor nanoparticles. J Vac Sci Technol B Microelectron Nanometer Struct. 2007;25(4):1441. doi:10.1116/1.2748415

16. Hewakuruppu YL, Dombrovsky LA, Chen C, et al. Plasmonic "pump-probe" method to study semi-transparent nanofluids. Appl Opt. 2013;52(24):6041. doi:10.1364/AO.52.006041

17. Malik R, Burch D, Bazant M, Ceder G. Particle size dependence of the ionic diffusivity. Nano Lett. 2010;10(10):4123-4127. doi:10.1021/nl1023595

18. Sun J, Wang F, Sui Y, et al. Effect of particle size on solubility, dissolution rate, and oral bioavailability: evaluation using coenzyme Q10 as naked nanocrystals. Int J Nanomedicine. 2012;7:5733-5744. doi:10.2147/IJN.S34365

19. Zhang D, Xu H, Hu MN, Deng YH. "PEG dilemma" for liposomes and its solving approaches. Acta Pharm Sin. 2015;50(3):252-260.

20. Xu W, Ling P, Zhang T. Polymeric micelles, a promising drug delivery system to enhance bioavailability of poorly water-soluble drugs. J Drug Deliv. 2013;2013:1-15. doi:10.1155/2013/340315

21. Morshed RA, Cheng Y, Auffinger B, Wegscheid ML, Lesniak MS. The potential of polymeric micelles in the context of glioblastoma therapy. Front Pharmacol. 2013;4. doi:10.3389/fphar.2013.00157

22. Elhissi A, Ahmed W, Dhanak V, Subramani K. Carbon nanotubes in cancer therapy and drug delivery. Emerging Nanotechnol Dent. 2012;2012:347-363.

23. Glaser T, Han I, Wu L, Zeng X. Targeted nanotechnology in glioblastoma multiforme. Front Pharmacol. 2017;8(166):1-14. doi:10.3389/fphar.2017.00166

24. Tomalia DA, Baker H, Dewald J, et al. Dendritic macromolecules: synthesis of starburst dendrimers. Macromol. 1986;19(9):2466-2468. doi:10.1021/ma00163a029

25. Newkome GR, Shreiner C. Dendrimers derived from $1 \rightarrow 3$ branching motifs. Chem Rev. 2010;110(10):6338-6442. doi:10.1021/ cr900341m

26. Maciejewski M. Concepts of trapping topologically by shell molecules. J Macromol Sci A. 1982;17(4):689-703. doi:10.1080/ 00222338208062416

27. Vögtle F, Richardt G, Werner N. Dendrimer Chemistry. Weinheim: WILEY-VCH Verlag GmbH \& Co. KGaA; 2009.

28. Alper J. Rising chemical "stars" could play many roles. Science. 1991;251(5001):1562-1564. doi:10.1126/science.2011736

29. Abbasi E, Aval SF, Akbarzadeh A, et al. Dendrimers: synthesis, applications, and properties. Nanoscale Res Lett. 2014;9(1):247. doi:10.1186/1556-276X-9-247

30. Wiesler U, Berresheim AJ, Morgenroth F, Lieser G, Müllen K. Divergent synthesis of polyphenylene dendrimers: the role of core and branching reagents upon size and shape. Macromol. 2001;34 (2):187-199. doi:10.1021/ma991519m

31. Grayson SM, Fréchet JM. Convergent dendrons and dendrimers: from synthesis to applications. Chem Rev. 2001;101(12):3819-3868. doi:10.1021/cr990116h

32. Naylor AM, Goddard WA, Kiefer GE, Tomalia DA. Starburst dendrimers. 5. Molecular shape control. J Am Chem Soc. 1989;111 (6):2339-2341. doi:10.1021/ja00188a079
33. Balendiran GK, Dabur R, Fraser D. The role of glutathione in cancer. Cell Biochem Funct. 2004;22(6):343-352. doi:10.1002/(ISSN)10990844

34. Perez AP, Cosaka ML, Romero EL, Morilla MJ. Uptake and intracellular traffic of siRNA dendriplexes in glioblastoma cells and macrophages. Int J Nanomedicine. 2011;6:2715-2728. doi:10.2147/ IJN.S25235

35. Kala S, Mak AS, Liu X, et al. Combination of dendrimer-nanovectormediated small interfering RNA delivery to target Akt with the clinical anticancer drug paclitaxel for effective and potent anticancer activity in treating ovarian cancer. $J$ Med Chem. 2014;57 (6):2634-2642. doi:10.1021/jm401907z

36. Liu X, Liu C, Laurini E, et al. Efficient delivery of sticky siRNA and potent gene silencing in a prostate cancer model using a generation 5 triethanolamine-core PAMAM dendrimer. Mol Pharm. 2012;9 (3):470-481. doi:10.1021/mp2006104

37. Yuba E, Nakajima Y, Tsukamoto K, et al. Effect of unsaturated alkyl chains on transfection activity of poly(amidoamine) dendron-bearing lipids. J Control Release. 2012;160(3):552-560. doi:10.1016/j. jconrel.2012.04.002

38. Christian P, Kammer FV, Baalousha M, Hofmann T. Nanoparticles: structure, properties, preparation and behaviour in environmental media. Ecotoxicol. 2008;17(5):326-343. doi:10.1007/s10646-0080213-1

39. Florendo M, Figacz A, Srinageshwar B, et al. Use of polyamidoamine dendrimers in brain diseases. Molecules. 2018;23(9):2238. doi:10.3390/molecules 23092238

40. Shadrack D, Swai H, Munissi J, Mubofu E, Nyandoro S. Polyamidoamine dendrimers for enhanced solubility of small molecules and other desirable properties for site specific delivery: insights from experimental and computational studies. Molecules. 2018;23 (6):1419. doi:10.3390/molecules23061419

41. Pandita D, Poonia N, Kumar S, Lather V, Madaan K. Dendrimers in drug delivery and targeting: drug-dendrimer interactions and toxicity issues. J Pharm Bioallied Sci. 2014;6(3):139. doi:10.4103/09757406.130965

42. Wiwattanapatapee R, Carreno-Gomez B, Malik N, Duncan R. Anionic PAMAM dendrimers rapidly cross adult rat intestine in vitro: A potential oral delivery system? Pharm. Res. 2000;17 (8):991-998. doi:10.1023/A:1007587523543

43. Florence AT. The oral absorption of micro-and nanoparticles: neither exceptional nor unusual. Pharm Res. 1997;14(3):259-266. doi:10.1023/A:1012029517394

44. Jain K, Kesharwani P, Gupta U, Jain N. Dendrimer toxicity: lets meet the challenge. Int $J$ Pharm. 2010;394(1-2):122-142. doi:10.1016/j. ijpharm.2010.04.027

45. Feliu N, Kohonen P, Ji J, et al. Next-generation sequencing reveals low-dose effects of cationic dendrimers in primary human bronchial epithelial cells. ACS Nano. 2015;9(1):146-163. doi:10.1021/ nn5061783

46. Naha PC, Davoren M, Casey A, Byrne HJ. An ecotoxicological study of poly(amidoamine)dendrimers-toward quantitative structure activity relationships. Environ Sci Technol. 2009;43(17):6864-6869. doi:10.1021/es $901017 \mathrm{v}$

47. Sadekar S, Ghandehari H. Transepithelial transport and toxicity of PAMAM dendrimers: implications for oral drug delivery. Adv Drug Deliv Rev. 2012;64(6):571-588. doi:10.1016/j.addr.2011.09.010

48. Golshaei P, Pourianazar NT. Surface modifications of cationic polyamidoamine (PAMAM) dendrimers. $J$ Biol Chem. 2014;4:485-497.

49. Araújo R, Santos S, Ferreira EI, Giarolla J. New advances in general biomedical applications of PAMAM dendrimers. Molecules. 2018;23 (11):2849. doi:10.3390/molecules23112849

50. Islam MT, Shi X, Balogh L, Baker JR. HPLC separation of different generations of poly(amidoamine) dendrimers modified with various terminal groups. Anal Chem. 2005;77(7):2063-2070. doi:10.1021/ ac048383x 
51. Lloyd JR, Jayasekara PS, Jacobson KA. Characterization of polyamidoamino (PAMAM) dendrimers using in-line reversed phase LC electrospray ionization mass spectrometry. Anal Methods. 2016;8 (2):263-269. doi:10.1039/C5AY01995H

52. Sharma A, Desai A, Ali R, Tomalia D. Polyacrylamide gel electrophoresis separation and detection of polyamidoamine dendrimers possessing various cores and terminal groups. $J$ Chromatogr A. 2005;1081(2):238-244. doi:10.1016/j.chroma.2005.05.074

53. Wang X, Guerrand L, Wu B, et al. Characterizations of polyamidoamine dendrimers with scattering techniques. Polymers. 2012;4 (1):600-616. doi:10.3390/polym 4010600

54. Yan H, Wang L, Wang J, et al. Two-order targeted brain tumor imaging by using an optical/paramagnetic nanoprobe across the blood brain barrier. ACS Nano. 2012;6(1):410-420. doi:10.1021/ nn203749v

55. Ren Y, Zhou X, Mei M, et al. MicroRNA-21 inhibitor sensitizes human glioblastoma cells U251 (PTEN-mutant) and LN229 (PTEN-wild type) to taxol. BMC Cancer. 2010;10(1):27. doi:10.1186/1471-2407-10-27

56. Ofek P, Fischer W, Calderón M, Haag R, Satchi-Fainaro R. In vivo delivery of small interfering RNA to tumors and their vasculature by novel dendritic nanocarriers. FASEB J. 2010;24(9):3122-3134. doi:10.1096/fj.09-149641

57. Mcnerny DQ, Kukowska-Latallo JF, Mullen DG, et al. RGD dendron bodies; synthetic avidity agents with defined and potentially interchangeable effector sites that can substitute for antibodies. Bioconjug Chem. 2009;20(10):1853-1859. doi:10.1021/bc900217h

58. Kaneshiro TL, Lu ZR. Targeted intracellular codelivery of chemotherapeutics and nucleic acid with a well-defined dendrimer-based nanoglobular carrier. Biomaterials. 2009;30 (29):5660-5666. doi:10.1016/j.biomaterials.2009.06.026

59. Singh MK, Kuncha M, Nayak VL, et al. An innovative in situ method of creating hybrid dendrimer nano-assembly: an efficient next generation dendritic platform for drug delivery. Nanomed. 2019;21:1-13.

60. Bae Y, Thuy LT, Lee YH, Ko KS, Han J, Choi JS. Polyplexes of functional PAMAM dendrimer/apoptin gene induce apoptosis of human primary glioma cells in vitro. Polymers. 2019;11(2):296. doi:10.3390/polym11020296

61. Munro NM, Fana M, Srinageshwar B, et al. Use of dendrimer nanoparticle encapsulated curcumin as a potential therapy for glioblastoma in mice. Cell Transplant. 2019;28(4):483.

62. Qiu J, Kong L, Cao X, et al. Enhanced delivery of therapeutic siRNA into glioblastoma cells using dendrimer-entrapped gold nanoparticles conjugated with $\beta$-cyclodextrin. Nanomater. 2018;8(3):131. doi: 10.3390/nano8030131

63. $€$ U, Szuster M, Misiorek M, et al. Cellular uptake of glucoheptoamidated poly(amidoamine) PAMAM G3 dendrimer with amide-conjugated biotin, a potential carrier of anticancer drugs. Bioorg Med Chem. 2017;25(2):706-713. doi:10.1016/j. bmc.2016.11.047

64. Janaszewska A, Lazniewska J, Trzepiński P, Marcinkowska M, Klajnert-Maculewicz B. Cytotoxicity of dendrimers. Biomolecules. 2019;9(8):330. doi:10.3390/biom9080330

65. Stenström P, Manzanares D, Zhang Y, Ceña V, Malkoch M. Evaluation of amino-functional polyester dendrimers based on Bis-MPA as nonviral vectors for siRNA delivery. Molecules. 2018;23(8):2028. doi:10.3390/molecules23082028

66. Choi J, Moquin A, Bomal E, Na L, Maysinger D, Kakkar A. Telodendrimers for physical encapsulation and covalent linking of individual or combined therapeutics. Mol Pharm. 2017;14 (8):2607-2615. doi:10.1021/acs.molpharmaceut.7b00019

67. Li N, Cai H, Jiang L, et al. Enzyme-sensitive and amphiphilic PEGylated dendrimer-paclitaxel prodrug-based nanoparticles for enhanced stability and anticancer efficacy. ACS Appl Mater Interfaces. 2017;9(8):6865-6877. doi:10.1021/acsami.6b15505
68. $\mathrm{Li} \mathrm{N}, \mathrm{Li} \mathrm{N}$, Yi Q, et al. Amphiphilic peptide dendritic copolymer-doxorubicin nanoscale conjugate self-assembled to enzyme-responsive anti-cancer agent. Biomaterials. 2014;35 (35):9529-9545. doi:10.1016/j.biomaterials.2014.07.059

69. Tang M, Dong H, Li Y, Ren T. Harnessing the PEG-cleavable strategy to balance cytotoxicity intracellular release and the therapeutic effect of dendrigraft poly-L-lysine for cancer gene therapy. J Mater Chem B. 2016;4(7):1284-1295. doi:10.1039/C5TB02224J

70. Bae Y, Green ES, Kim GY, et al. Dipeptide-functionalized polyamidoamine dendrimer-mediated apoptin gene delivery facilitates apoptosis of human primary glioma cells. Int $J$ Pharm. 2016;515 (1-2):186-200. doi:10.1016/j.ijpharm.2016.09.083

71. Bae Y, Song SJ, Mun JY, Ko KS, Han J, Choi JS. Apoptin gene delivery by the functionalized polyamidoamine (PAMAM) dendrimer modified with ornithine induces cell death of HepG2 cells. Polymers. 2017;9(12):197. doi:10.3390/polym9060197

72. Pedro-Hernandez LD, Martinez-Klimova E, Cortez-Maya S, Mendoza-Cardozo S, Ramirez-Apan T, Martinez-Garcia M. Synthesis, characterization, and nanomedical applications of conjugates between resorcinarene-dendrimers and ibuprofen. Nanomater. 2017;7(7):163. doi:10.3390/nano7070163

73. Janiszewska J, Posadas I, Játiva P, Bugaj-Zarebska M, UrbanczykLipkowska Z, Ceña V. Second generation amphiphilic poly-lysine dendrons inhibit glioblastoma cell proliferation without toxicity for neurons or astrocytes. PLoS One. 2016;11(11):e0165704. doi:10.1371/journal.pone.0165704

74. Zhang F, Mastorakos P, Mishra MK, et al. Uniform brain tumor distribution and tumor associated macrophage targeting of systemically administered dendrimers. Biomaterials. 2015;52:507-516. doi:10.1016/j.biomaterials.2015.02.053

75. Jiang Y, Lv L, Shi H, et al. PEGylated Polyamidoamine dendrimer conjugated with tumor homing peptide as a potential targeted delivery system for glioma. Colloids Surf $B$ Biointerfaces. 2016;147:242-249. doi:10.1016/j.colsurfb.2016.08.002

76. Zhao J, Zhang B, Shen S, et al. CREKA peptide-conjugated dendrimer nanoparticles for glioblastoma multiforme delivery. $J$ Colloid Interface Sci. 2015;450:396-403. doi:10.1016/j.jcis.2015.03.019

77. Wu Y, Fan Q, Zeng F, et al. Peptide-functionalized nanoinhibitor restrains brain tumor growth by abrogating mesenchymal-epithelial transition factor (MET) signaling. Nano Lett. 2018;18(9):5488-5498. doi:10.1021/acs.nanolett.8b01879

78. $Ł$ U, Filipowicz A, Misiorek M, et al. Biotinylated PAMAM G3 dendrimer conjugated with celecoxib and/or Fmoc-1-Leucine and its cytotoxicity for normal and cancer human cell lines. Eur J Pharm Sci. 2018;124:1-9. doi:10.1016/j.ejps.2018.08.019

79. $Ł$ U, Misiorek M, Pichla M, et al. The effect of biotinylated PAMAM G3 dendrimers conjugated with COX-2 inhibitor (celecoxib) and PPARr agonist (Fmoc-L-Leucine) on human normal fibroblasts, immortalized keratinocytes and glioma cells in vitro. Molecules. 2019;24(20):3801. doi:10.3390/molecules24203801

80. Jiao J, Ishikawa TO, Dumlao DS, et al. Targeted deletion and lipidomic analysis identify epithelial cell COX-2 as a major driver of chemically induced skin cancer. Mol Cancer Res. 2014;12 (11):1677-1688. doi:10.1158/1541-7786.MCR-14-0397-T

81. Knopfová L, Šmarda J. The use of Cox-2 and PPAR $\gamma$ signaling in anti-cancer therapies. Exp. Ther. Med. 2010;1(2):257-264. doi:10.3892/etm_00000040

82. Vella V, Nicolosi ML, Giuliano S, Bellomo M, Belfiore A, Malaguarnera R. PPAR- $\gamma$ agonists as antineoplastic agents in cancers with dysregulated IGF axis. Front Endocrinol (Lausanne). 2017;8:31. doi:10.3389/fendo.2017.00031

83. Dhermain FG, Hau P, Lanfermann H, Jacobs AH, Bent MJVD Advanced MRI and PET imaging for assessment of treatment response in patients with gliomas. Lancet Neurol. 2010;9 (9):906-920. doi:10.1016/S1474-4422(10)70181-2 
84. Hardee ME, Zagzag D. Mechanisms of glioma-associated neovascularization. Am J Pathol. 2012;181(4):1126-1141. doi:10.1016/ j.ajpath.2012.06.030

85. Oberoi RK, Parrish KE, Sio TT, et al. Strategies to improve delivery of anticancer drugs across the blood-brain barrier to treat glioblastoma. Neurooncol. 2016;18(1):27-36. doi:10.1093/neuonc/ nov164

86. Sarkaria JN, Hu LS, Parney IF, et al. Is the blood-brain barrier really disrupted in all glioblastomas? A critical assessment of existing clinical data. Neuro-Oncology. 2018;20(2):184-191. doi:10.1093/ neuonc/nox 175

87. Liu FH, Hou CY, Zhang D, et al. Enzyme-sensitive cytotoxic peptide-dendrimer conjugates enhance cell apoptosis and deep tumor penetration. Biomater Sci. 2018;6(3):604-613. doi:10.1039/ C7BM01182B
88. Yang HW, Huang CY, Lin CW, et al. Gadolinium-functionalized nanographene oxide for combined drug and microRNA delivery and magnetic resonance imaging. Biomaterials. 2014;35(24):6534-6542. doi:10.1016/j.biomaterials.2014.04.057

89. Bai CZ, Choi S, Nam K, An S, Park JS. Arginine modified PAMAM dendrimer for interferon beta gene delivery to malignant glioma. Int J Pharm. 2013;445(1-2):79-87. doi:10.1016/j.ijpharm.2013.01. 057

90. Lesniak WG, Oskolkov N, Song X, et al. Salicylic acid conjugated dendrimers are a tunable, high performance CEST MRI nanoplatform. Nano Lett. 2016;16(4):2248-2253. doi:10.1021/acs. nanolett. $5 \mathrm{~b} 04517$

91. Kesharwani P, Banerjee S, Gupta U, et al. PAMAM dendrimers as promising nanocarriers for RNAi therapeutics. Mater Today. 2015;18 (10):565-572. doi:10.1016/j.mattod.2015.06.003

\section{Publish your work in this journal}

The International Journal of Nanomedicine is an international, peerreviewed journal focusing on the application of nanotechnology in diagnostics, therapeutics, and drug delivery systems throughout the biomedical field. This journal is indexed on PubMed Central, MedLine, CAS, SciSearch ${ }^{\mathbb{R}}$, Current Contents ${ }^{\mathbb{R}} /$ Clinical Medicine, $^{-}$
Journal Citation Reports/Science Edition, EMBase, Scopus and the Elsevier Bibliographic databases. The manuscript management system is completely online and includes a very quick and fair peer-review system, which is all easy to use. Visit http://www.dovepress.com/ testimonials.php to read real quotes from published authors. 